\title{
Tuning Activity and Selectivity during Alkyne Activation by Gold(I)/ Platinum(0) Frustrated Lewis Pairs
}

\author{
Nereida Hidalgo, Juan José Moreno, Marina Pérez-Jiménez, Celia Maya, Joaquín López-Serrano,* \\ and Jesús Campos*
}

Cite This: Organometallics 2020, 39, 2534-2544

Read Online

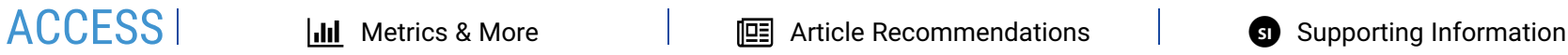

ABSTRACT: Introducing transition metals into frustrated Lewis pair systems has attracted considerable attention in recent years. Here we report a selection of three metal-only frustrated systems based on $\mathrm{Au}(\mathrm{I}) / \mathrm{Pt}(0)$ combinations and their reactivity toward alkynes. We have inspected the activation of acetylene and phenylacetylene. The gold(I) fragments are stabilized by three bulky phosphines bearing terphenyl groups. We have observed that subtle modifications on the substituents of these ligands proved critical in controlling the regioselectivity of acetylene activation and the product distribution resulting from $\mathrm{C}(\mathrm{sp})-\mathrm{H}$ cleavage of phenylacetylene. A mechanistic picture based on experimental observations and computational analysis is provided. As a result of the cooperative action of the

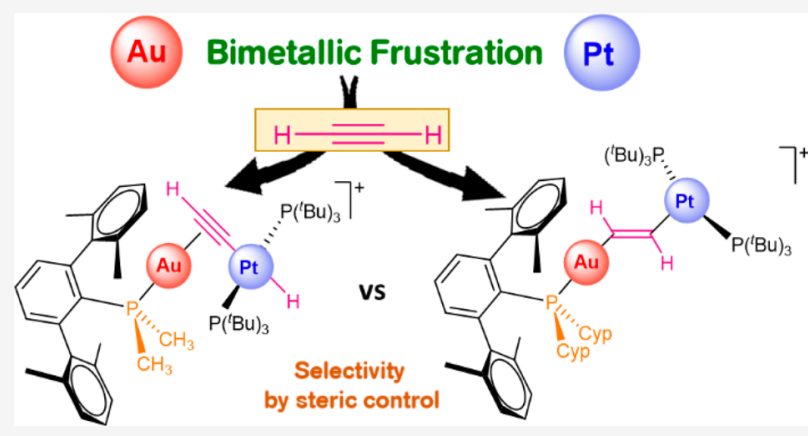
two metals of the frustrated pairs, several uncommon heterobimetallic structures have been characterized.

\section{INTRODUCTION}

Frustrated Lewis pairs (FLPs) emerged more than a decade ago as a paradigmatic example of chemical cooperativity, permitting bond activation and catalysis in the absence of transition metals. ${ }^{1}$ However, the incorporation of the latter as core components of FLP systems has also attracted considerable attention in the last few years. ${ }^{2,3}$ In fact, the concept of frustration may be applied to a wide variety of transition-metalmediated transformations that were described considerably earlier than the emergence of FLP chemistry and have so far been associated with the broader concept of chemical cooperativity. From an awareness of this sometimes diffuse frontier between "traditional" transition-metal cooperative chemistry and metallic frustration, the introduction of the latter concept remains useful as a driving force for the discovery of novel transformations. That being said, introducing transition metals into frustrated designs largely increases the amount and structural diversity of Lewis acid/base combinations available. In addition, it provides an array of elementary reactions accessible for transition metals that is foreseen to extend the catalytic usefulness of main-group FLPs beyond their current status. However, a fundamental knowledge on transition-metal FLPs regarding mechanistic aspects, solution dynamics, acidbase interactions, and selectivity effects is rather underexplored in comparison to main-group FLPs, despite the fact that this information is vital for expeditious catalyst development.

In this regard, the Wass group demonstrated that subtle ligand modifications have a strong effect on the ability of zirconocenebased FLPs toward dihydrogen splitting. ${ }^{4}$ This type of system was also examined to clarify the nature of Lewis acid-base interactions by DOSY NMR spectroscopy. ${ }^{5}$ Going beyond monometallic systems, our group focused on gaining a fundamental knowledge of FLPs in which the two Lewis components are based on transition metals. Thus, we recently reported the first example of its kind by combining $\mathrm{Au}(\mathrm{I})$ and $\operatorname{Pt}(0)$ species as the acidic and basic sites, respectively. ${ }^{6}$ To achieve frustration, we targeted sterically hindered phosphine ligands for both gold and platinum monometallic complexes. Our experimental/computational investigations regarding the heterolytic splitting of dihydrogen mediated by these pairs led us to propose a genuine bimetallic FLP-type pathway ${ }^{7}$ analogous to the models assumed for main-group counterparts. ${ }^{8}$ Moreover, we could analyze the strong influence that $\mathrm{Au} \cdots \mathrm{Pt}$ interactions have on the activation capacity of the bimetallic pairs, as well as the solution dynamic equilibria between the metal-only Lewis pairs and the individual monometallic fragments. This is a particularly important aspect in the field of FLPs that has been widely investigated for metal-free systems, where the term "thermally induced FLPs" 9 was coined to refer those pairs in which the Lewis adduct is the resting state. Despite this fact, many of these pairs exhibit a rich FLP reactivity ${ }^{10}$ and in some

Received: May 11, 2020

Published: June 29, 2020 
cases catalytic performance superior to that of their fully frustrated counterparts. ${ }^{11}$

In this study, we extend our fundamental knowledge on transition-metal-only FLPs (TMOFLPs) by exploring regioselectivity effects derived from ligand modification during the activation of alkynes, also model substrates widely investigated in the field of frustrated systems. ${ }^{1,12}$ We have focused on the effects derived from varying the degree of frustration, for which we have used terphenylphosphine ligands $\mathrm{PMe}_{2} \mathrm{Ar}^{\mathrm{Xyl2}}$ (a), $\mathrm{PMe}_{2} \mathrm{Ar}^{\mathrm{Dipp} 2}$ (b), and PCyp $2 \mathrm{Ar}^{\mathrm{Xyl2}}$ (c) (Cyp = cyclopentyl), with different steric profiles, to stabilize electrophilic gold fragments 1 (Figure 1). These acidic complexes combined with the basic

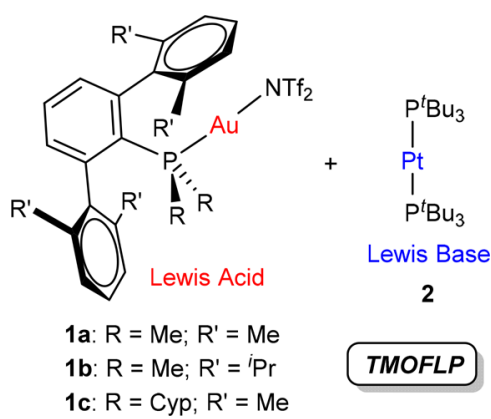

Figure 1. $\mathrm{Au}(\mathrm{I}) / \mathrm{Pt}(0)$ transition-metal-only frustrated Lewis pair (TMOFLP) combinations used in this work (Cyp = cyclopentyl; $\mathrm{NTf}_{2}{ }^{-}$ $=\mathrm{N}\left(\mathrm{SO}_{2} \mathrm{CF}_{3}\right)_{2}^{-}=$triflimide $)$.

$\mathrm{Pt}(0)$ compound $\left[\mathrm{Pt}\left(\mathrm{P}^{t} \mathrm{Bu}_{3}\right)_{2}\right]$ (2) promote the cooperative activation of terminal alkynes. Our studies demonstrate the potential of using transition-metal Lewis acids (i.e., $\left[\mathrm{PR}_{3} \mathrm{Au}^{\mathrm{I}}\right]^{+}$ fragments) to control the selectivity in the activation of small molecules by tuning the steric properties of the ancillary ligands. This is particularly appealing in view of the challenging available protocols to synthesize the typically used acidic boranes and their scant stability toward moisture. ${ }^{13}$

\section{RESULTS AND DISCUSSION}

To investigate regioselectivity effects during alkyne activation, we first examined the reactivity of the three $\mathrm{Au} / \mathrm{Pt}$ bimetallic pairs depicted in Figure 1 toward acetylene, a reaction that we had previously reported with the $\mathbf{1 b}: \mathbf{2}$ combination. ${ }^{6 a}$ When a dichloromethane or benzene solution of the latter pair is exposed to acetylene $\left(0.5 \mathrm{bar}, 25^{\circ} \mathrm{C}\right)$, a rapid color change from bright yellow to intense orange takes place. Multinuclear NMR spectroscopic analysis revealed the formation of a clean mixture of two structurally different isomers, namely a bridging $\sigma, \pi$ acetylide (3b) and a rather unusual heterobimetallic vinylene $(-\mathrm{CH}=\mathrm{CH}-)(4 \mathbf{b})$, which are produced in a $4: 1$ ratio
(Scheme 1). These metallic species are highly reminiscent of the organic products derived from the reactivity of traditional phosphine/borane FLPs with alkynes, where the prevalence of one or the other isomer typically depends on the basicity of the phosphine. $^{14}$

We now tested the analogous reactivity using the gold precursors $\left[\left(\mathrm{PMe}_{2} \mathrm{Ar}^{\mathrm{Xyl} 2}\right) \mathrm{Au}\left(\mathrm{NTf}_{2}\right)\right](\mathbf{1 a})$ and $\left[\left(\mathrm{PCyp}_{2} \mathrm{Ar}^{\mathrm{Xyl} 2}\right)\right.$ $\left.\mathrm{Au}\left(\mathrm{NTf}_{2}\right)\right]$ (1c) in our search for regioselectivity effects, while the basicity of the metallic base was kept unaltered (2). Moreover, the acidities of the gold precursors $\mathbf{1 a}-\mathbf{c}$ barely differ from one another; ${ }^{15}$ thus, any anticipated outcomes mostly build on steric grounds. In fact, we found a drastic change in product distribution from the less hindered system (1a, $\mathrm{PMe}_{2} \mathrm{Ar}^{\mathrm{Xy} 2}$ ) to the more congested one (1c, $\left.\mathrm{PCyp}_{2} \mathrm{Ar}^{\mathrm{Xyl} 2}\right)$, as determined by NMR spectroscopy. While the former yields around $95 \%$ of the bridging $\mathrm{Au} / \mathrm{Pt}$ acetylide $3 \mathrm{a}$ and only a residual amount of the vinylene $(4 a,<5 \%)$, the more hindered pair comprising the $\left[\left(\mathrm{PCyp}_{2} \mathrm{Ar}^{\mathrm{Xyl} 2}\right) \mathrm{Au}\right]^{+}$fragment (1c) fully reversed the selectivity toward the exclusive formation of the corresponding vinylene $4 \mathrm{c}$ (Scheme 1$)$. Attempts to isolate $3 \mathrm{c}$ by the reaction of independently prepared compounds $\left[\left(\mathrm{PCyp}_{2} \mathrm{Ar}^{\mathrm{Xyl}}\right) \mathrm{Au}(\mathrm{C} \equiv \mathrm{CH})\right](\mathbf{5 c})$ and $\left[\mathrm{Pt}\left(\mathrm{P}^{t} \mathrm{Bu}_{3}\right)_{2} \mathrm{H}\right]\left[\mathrm{NTf}_{2}\right]^{16}$ (6) proved unsuccessful and resulted in intractable mixtures.

As mentioned above, this dramatic shift in regioselectivity seems to be dominated by steric effects, which contrasts with prior strategies to modulate alkyne activation by FLPs that mostly rely on phosphine basicity. More importantly, it evinces the potential of FLP systems that incorporate transition-metal Lewis acids to easily tune the selectivity during bond activation processes and, as such, in subsequent catalytic applications that incorporate those activation events. As was pointed out earlier, this could be seen as a key advantage in comparison to traditional FLP designs that usually involve fluorinated boranes, since accessing these moieties already entails substantial synthetic challenges and limitations, not to mention their limited stability toward moisture and air. ${ }^{13}$ In stark contrast, the preparation of terphenylphosphines $\mathrm{PR}_{2} \mathrm{Ar}^{\prime}$ is straightforward and highly versatile, ${ }^{17}$ while the resulting gold precursors $\mathbf{1}$ are readily obtained in high yields and exhibit stability toward water or under moderate oxidizing conditions. ${ }^{18}$

The nature of the new heterobimetallic compounds $3 a$ and $4 c$ was ascertained by a comparison of their ${ }^{1} \mathrm{H}$ and ${ }^{31} \mathrm{P}\left\{{ }^{1} \mathrm{H}\right\} \mathrm{NMR}$ signals with those derived from their analogous species based on $\mathrm{PMe}_{2} \mathrm{Ar}^{\mathrm{Dipp} 2}$ : that is, $3 \mathbf{b}$ and $\mathbf{4 b}$, respectively. ${ }^{6 \mathrm{a}}$ The heterobimetallic nature of compounds 4 is evinced by the ${ }^{195} \mathrm{Pt}$ satellites that flank the ${ }^{31} \mathrm{P}\left\{{ }^{1} \mathrm{H}\right\}$ resonances associated with terphenylphosphines, which appear at $2.1\left(4 \mathbf{b},{ }^{4} J_{\mathrm{PPt}}=282 \mathrm{~Hz}\right)$ and $51.7\left(4 \mathrm{c},{ }^{4} J_{\mathrm{PPt}}=277 \mathrm{~Hz}\right)$ ppm. The bridging vinylene $(-\mathrm{CH}=\mathrm{CH}-)$ moiety displays a distinctive pair of ${ }^{1} \mathrm{H}$ NMR

Scheme 1. Regioselectivity in the Activation of Acetylene by TMOFLPs 1:2

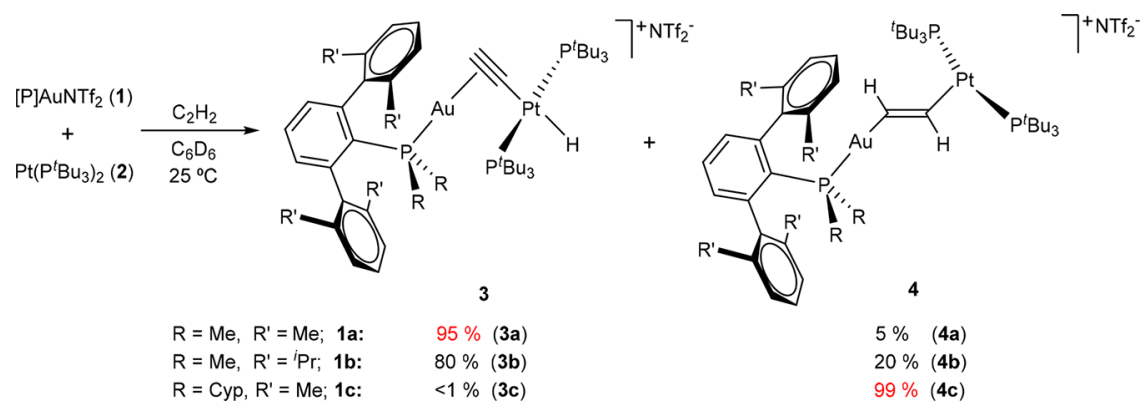


signals in the region between 4.0 and $4.5 \mathrm{ppm}$ that reveal scalar coupling to the ${ }^{195} \mathrm{Pt}$ center in the range $120-200 \mathrm{~Hz}$ (see the Experimental Section for details). By analogy, we attribute a ${ }^{31} \mathrm{P}\left\{{ }^{1} \mathrm{H}\right\}$ NMR resonance at $3.67 \mathrm{ppm}$ to the minor species (ca. $5 \%$ ) in the $\mathrm{PMe}_{2} \mathrm{Ar}^{\mathrm{Xyl2}}$ system (4a), with an identical ${ }^{1} \mathrm{H}$ NMR pattern comprised of signals at 4.54 and $4.37 \mathrm{ppm}$, though their corresponding ${ }^{195} \mathrm{Pt}$ satellites could not be observed due to the low concentration of isomer $4 \mathrm{a}$. Corresponding ${ }^{13} \mathrm{C} \mathrm{NMR}$ resonances for compounds $4 \mathbf{b}, \mathbf{c}$ emerge at ca. $155\left({ }^{1} J_{\mathrm{CH}} \approx 175\right.$ $\mathrm{Hz})$ and $115\left({ }^{1} J_{\mathrm{CH}} \approx 190 \mathrm{~Hz}\right) \mathrm{ppm}$, respectively, supporting the proposed formulation and the $\mathrm{sp}^{2}$ hybridization of the carbon atoms.

The molecular structure of compounds $3 \mathbf{a}$ and $\mathbf{4 c}$ was further corroborated by X-ray diffraction studies (Figure 2). The
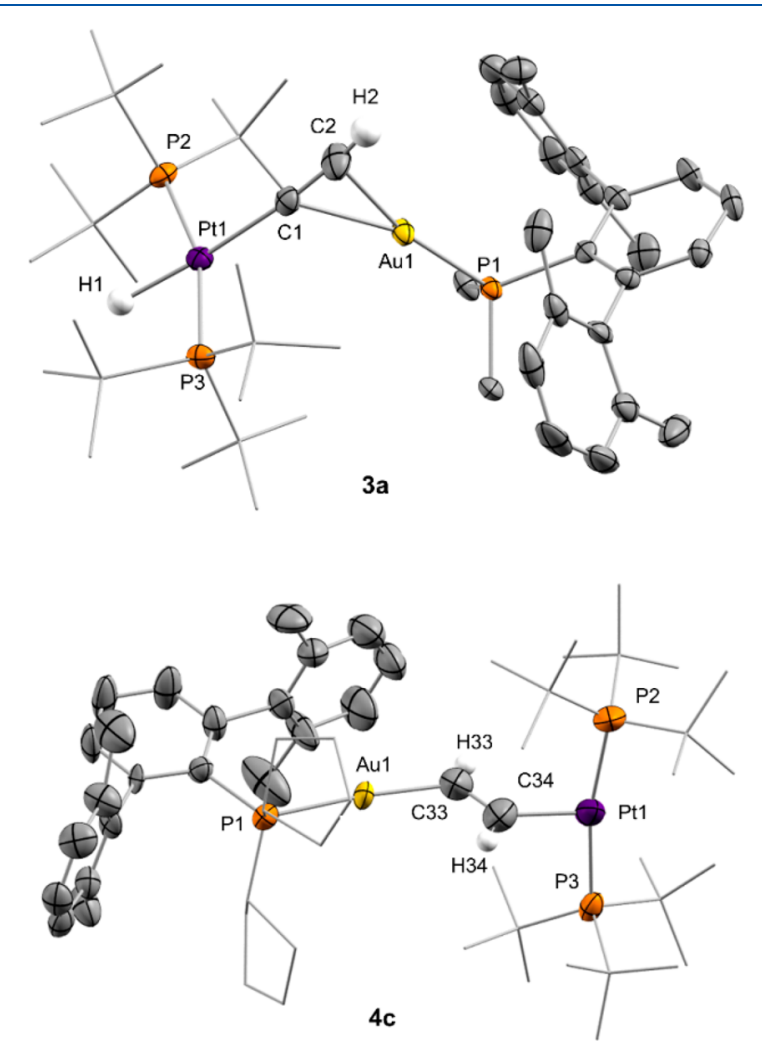

Figure 2. ORTEP diagrams of compounds $3 a$ and $4 c$. For the sake of clarity most hydrogen atoms and triflimide anions are excluded and some substituents have been represented in wireframe format, while thermal ellipsoids are set at 50\% probability.

presence of the $\sigma, \pi$-acetylide or vinylene linker distorts the linearity around the platinum center: $\mathrm{P}-\mathrm{Pt}-\mathrm{P}$ angles of around $165^{\circ}$, shifted from the ideal $180^{\circ}$ due to the steric pressure exerted by the bulky gold fragments. The Pt1-C1 (2.016(6) $\AA$ ) and Au1-C1 (2.311(5) $\AA$ ) bond distances in 3a appear slightly shortened in comparison to $3 \mathbf{b}\left(d_{\mathrm{Pt} 1-\mathrm{C} 1}=2.044(7) \AA \AA_{\mathrm{Au} 1-\mathrm{C} 1}=\right.$ 2.360(7) $\AA$ ). The average $\mathrm{C}=\mathrm{C}$ bond distance of the vinylene linkers in the two crystallographically independent molecules of 4c accounts for $1.278(13) \AA$, comparable to those of $\mathbf{4 b}$ (1.287(11) ^̊). These and other geometric features are similar to those of previously reported related species. ${ }^{19}$

We had previously observed that the three investigated terphenylphosphines permit control of the equilibrium between complete frustration and bimetallic adduct formation. ${ }^{7}$ Thus, while a dative $\mathrm{Pt} \rightarrow \mathrm{Au}$ bond is immediately formed between $\left[\left(\mathrm{PMe}_{2} \mathrm{Ar}^{\mathrm{Xyl} 2}\right) \mathrm{Au}\left(\mathrm{NTf}_{2}\right)\right]$ (1a) and $\left[\mathrm{Pt}\left(\mathrm{P}^{t} \mathrm{Bu}_{3}\right)_{2}\right]$ (2), the formation of an identical adduct based on $\mathrm{PCyp}_{2} \mathrm{Ar}^{\mathrm{Xyl} 2}$ is endergonic and could not be experimentally detected. An intermediate situation is reached for the medium-sized phosphine $\mathrm{PMe}_{2} \mathrm{Ar}^{\mathrm{Dipp} 2}$, where the prevalence of the monometallic fragments or the bimetallic adduct depends upon experimental conditions. In this context, we have observed that TMOFLPs (1:2) based on the gold precursors $\left[\left(\mathrm{PMe}_{2} \mathrm{Ar}^{\mathrm{Dipp} 2}\right)\right.$ $\left.\mathrm{Au}\left(\mathrm{NTf}_{2}\right)\right]$ (1b) and [( $\left.\left.\mathrm{PCyp}_{2} \mathrm{Ar}^{\mathrm{Xyl}}\right) \mathrm{Au}\left(\mathrm{NTf}_{2}\right)\right]$ (1c) are considerably more active toward alkyne activation in comparison to that one built on $\left[\left(\mathrm{PMe}_{2} \mathrm{Ar}^{\mathrm{Xyl}}\right) \mathrm{Au}\left(\mathrm{NTf}_{2}\right)\right](\mathbf{1 a})$. While full conversion toward compounds 3 and $\mathbf{4}$ was recorded by the time of placing the sample in the NMR probe $(<5 \mathrm{~min})$ in the case of using $1 \mathrm{~b}: 2$ or $1 \mathrm{c}: 2$, the analogous transformation essayed with 1 a required up to $24 \mathrm{~h}$ to reach completion under otherwise identical conditions $\left(\mathrm{C}_{2} \mathrm{H}_{2}, 0.5\right.$ bar, $25^{\circ} \mathrm{C}$, toluene or $\left.\mathrm{C}_{6} \mathrm{D}_{6}\right)$. This fact speaks in favor of a genuine FLP mechanism that imposes an energetic demand to overcome the $\mathrm{Pt} \rightarrow \mathrm{Au}$ bond cleavage prior to acetylene activation, a requirement that only applies to the less hindered gold precursor 1a. Similar effects have been observed in the gold-catalyzed addition of $\mathrm{P}$ nucleophiles to alkynes. $^{20}$

In addition, it is key to highlight that the cooperative reactivity depicted in Scheme 1 contrasts with that of the individual $\mathrm{Au}(\mathrm{I})$ or $\mathrm{Pt}(0)$ fragments (Scheme 2). For instance, $\left[\mathrm{Pt}\left(\mathrm{P}^{t} \mathrm{Bu}_{3}\right)_{2}\right]$ (2) readily catalyzes acetylene polymerization, evinced by the rapid formation of a purple-black solid accompanied by the disappearance of a ${ }^{1} \mathrm{H}$ NMR resonance at $1.34 \mathrm{ppm}$ due to $\mathrm{C}_{2} \mathrm{H}_{2}$, while signals due to 2 remained unchanged. At variance, no indication of polyacetylene formation is apparent when gold

Scheme 2. (A) Reactivity of Individual Gold (1) and Platinum (2) Compounds toward Acetylene and (B) Reaction of $\sigma, \pi$-Acetylide $7 \mathrm{~b}$ and T-shaped Platinum Hydride 6

(A)

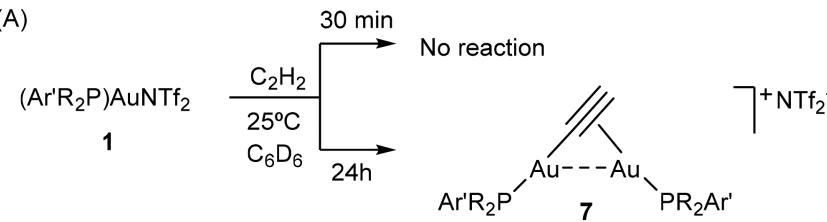

$<50 \%$ (+ other minor products)

$\underset{2}{\mathrm{Pt}\left(\mathrm{P}^{t} \mathrm{Bu}_{3}\right)_{2}} \stackrel{\mathrm{C}_{2} \mathrm{H}_{2}}{\underset{2}{\mathrm{C}_{6} \mathrm{D}_{6}, 25^{\circ} \mathrm{C}}} \underset{\mathbf{2}}{\mathrm{Pt}\left(\mathrm{P}^{t} \mathrm{Bu}_{3}\right)_{2}}+$ Polyacetylene

(B)

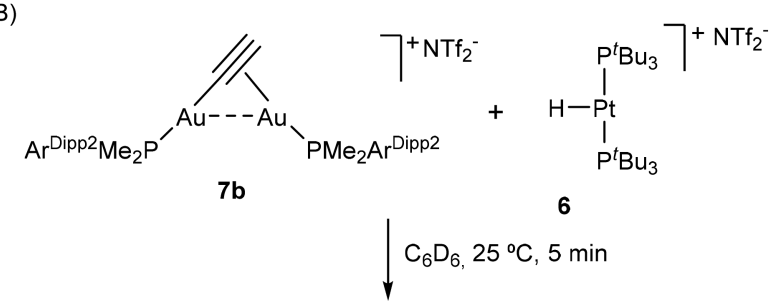

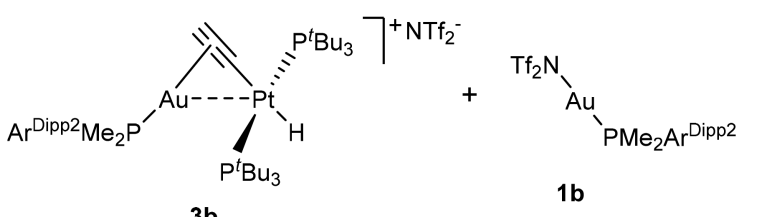


is also present in solution. In the case of the individual gold compounds 1 there is no sign of chemical transformation in the short term (ca. $30 \mathrm{~min}$ ), while at longer reaction times the gold triflimide precursors evolve to bridging $\sigma, \pi$-acetylide compounds 7 (Scheme $2 \mathrm{~A}),{ }^{21}$ albeit only in moderate yields accompanied by other unidentified gold-containing species.

Having the previous experimental findings on hand, we were interested in further understanding the cooperative action of TMOFLPs 1:2 to gain a fundamental knowledge of significance for future catalytic applications. As such, we initially wondered about the possible role of acetylide-bridged digold compounds such as 7 as precursors toward complexes 3 and 4 . In fact, the reaction between $7 \mathbf{b}$ and $\left[\mathrm{Pt}\left(\mathrm{P}^{t} \mathrm{Bu}_{3}\right)_{2} \mathrm{H}\right]\left[\mathrm{NTf}_{2}\right](6)$ immediately yielded the corresponding heterobimetallic $\sigma, \pi$-acetylide compound $3 \mathbf{b}$, where the unsaturated linker is now $\sigma$-bonded to the platinum center instead of the gold nucleus. Nevertheless, the complete absence of the vinylene isomer $4 b$ during the latter reaction would require an additional competing route to provide access to this unusual bimetallic motif, which actually is the exclusive isolated isomer for the bulkier $\mathrm{PCyp}_{2} \mathrm{Ar}^{\mathrm{Xy12}}$-based system (Scheme 1). Moreover, the formation of compounds 7 requires several hours to proceed to appreciable conversions, while the activation of acetylene by $1: 2$ pairs is immediate $(<5$ $\mathrm{min})$, except for the gold precursor $1 \mathrm{a}$ bearing $\mathrm{PMe}_{2} \mathrm{Ar}^{\mathrm{Xyl}}$, which as noted earlier takes around $24 \mathrm{~h}$ to convert into $3 \mathrm{a}$ in the presence of $\left[\mathrm{Pt}\left(\mathrm{P}^{t} \mathrm{Bu}_{3}\right)_{2}\right](2)$.

To further investigate the mechanism and the reasons for the drastically different regioselectivity observed, we carried out computational studies (DFT, $\omega \mathrm{B} 97 \mathrm{XD} / 6-31 \mathrm{G}(\mathrm{d}, \mathrm{p})+\mathrm{SDD})$. Focusing on the system based on $\mathrm{PMe}_{2} \mathrm{Ar}^{\mathrm{Dipp} 2}$, we began searching for initial acetylene activation steps by approaching the acetylene molecule to the individual $\mathrm{Au}(\mathrm{I})(\mathbf{1 b})$ and $\mathrm{Pt}(0)$ (2) fragments, assuming that $\mathrm{Au}-\mathrm{Pt}$ dissociation is a prerequisite for alkyne activation, as deduced from the reduced reactivity of the pair $1 \mathrm{a}: 2$ in comparison to $\mathbf{1 b}: \mathbf{2}$ and $\mathbf{1 c}: \mathbf{2}$ and previous computational results. ${ }^{7}$ Interestingly, the formation of 3 and $\mathbf{4}$ seems to share a common intermediate, namely a $\mathrm{Au}(\mathrm{I})$ acetylene adduct of formula $\left[\left(\mathrm{PR}_{2} \mathrm{Ar}^{\prime}\right) \mathrm{Au}\left(\mathrm{C}_{2} \mathrm{H}_{2}\right)\right]^{+}(9)$. The formation of this type of $\pi$ complex has been previously proposed in the context of alkyne $\mathrm{e}^{12,14 a}$ and alkene $\mathrm{a}^{22}$ activation by $\mathrm{P} / \mathrm{B}$ pairs, but no experimental proofs of their existence have been reported. In an attempt to spectroscopically identify such an intermediate, we recorded the formation of a new goldcontaining species by low-temperature $\operatorname{NMR}\left(-80{ }^{\circ} \mathrm{C}\right)$ as the major species (ca. $80 \%$ ) upon exposing a $\mathrm{CD}_{2} \mathrm{Cl}_{2}$ solution of $\mathbf{1 b}$ to an acetylene atmosphere. This species exhibits a distinctive ${ }^{1} \mathrm{H}$ NMR signal at $3.43 \mathrm{ppm}$ that correlates with a ${ }^{31} \mathrm{P}$ NMR resonance at $-0.3 \mathrm{ppm}$ (in comparison to $\delta_{\mathrm{P}}-9.9 \mathrm{ppm}$ for $\mathbf{1 b}$ ) and presents dynamic exchange with free acetylene $\left(\delta_{\mathrm{H}} 2.11\right.$ ppm) as seen by EXSY NMR experiments, while other ${ }^{1} \mathrm{H}$ NMR resonances are comparable to those of $\mathbf{1 b}$. This finding constitutes an additional benefit of TMFLPs for mechanistic investigations in frustrated systems, since they provide additional modes of stabilizing otherwise fleeting intermediates.

With the acetylene adduct $9 \mathbf{b}$ as the starting point, our calculations indicate that the attack of the platinum compound 2 over $\mathbf{9 b}$ leads to either of the two bimetallic isomers $\mathbf{3 b}$ and $\mathbf{4 b}$ depending on the trajectory followed by 2 while it approaches 9b (Figure 3). Thus, if 2 approaches the acetylene adduct along the $\mathrm{Au}-\mathrm{C}_{2} \mathrm{H}_{2}$ direction, the corresponding vinylene $4 \mathbf{b}$ forms $\left(\Delta G^{\ddagger}=23.4 \mathrm{kcal} \mathrm{mol}^{-1}\right.$ from the $1 \mathbf{b}: 2$ Lewis pair + acetylene $)$, in a process somehow reminiscent of the gold-mediated nucleophilic attack over activated alkynes (e.g., gold-catalyzed

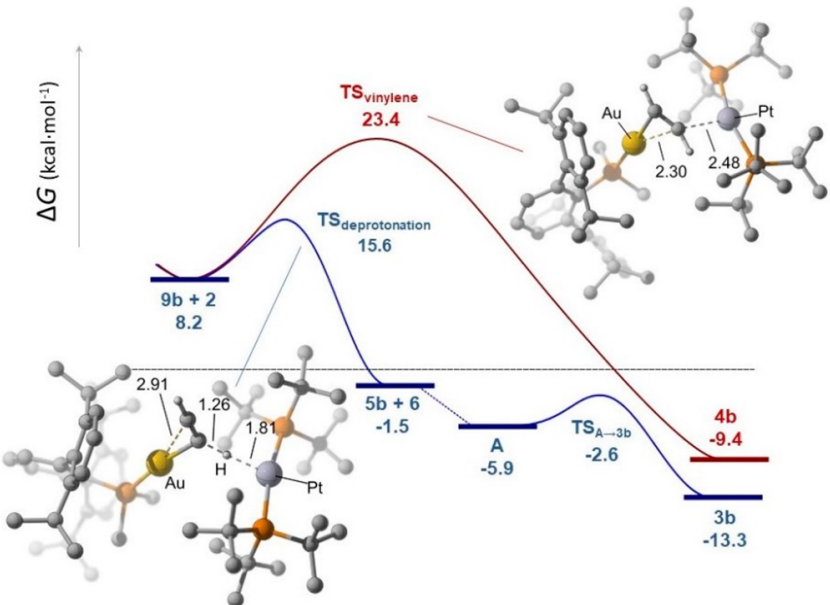

Figure 3. Energy profiles for the formation of the acetylide and vinylene complexes $\mathbf{3 b}$ and $\mathbf{4 b}$ from the common intermediate $\mathbf{9 b}$ and platinum(0) compound $\mathbf{2}$. The origin of energies is set to the $\mathbf{1 b}: \mathbf{2}$ Lewis pair + acetylene.

hydroamination). ${ }^{23}$ In contrast, the alignment of the basic 2 in an orthogonal disposition with respect to the $\mathrm{Au}-\mathrm{C}_{2} \mathrm{H}_{2}$ bond results in deprotonation of the activated acetylene (15.6 kcal $\mathrm{mol}^{-1}$ for the pair $\left.\mathbf{1 b}: 2\right)$ to yield the corresponding $\mathrm{Au}(\mathrm{I})$ terminal acetylide $\left[\left(\mathrm{PMe}_{2} \mathrm{Ar}^{\mathrm{Dipp}^{2}}\right) \mathrm{Au}(\mathrm{C} \equiv \mathrm{CH})\right](\mathbf{5 b})$ and $\left[\mathrm{Pt}\left(\mathrm{P}^{t} \mathrm{Bu}_{3}\right)_{2} \mathrm{H}\right]\left[\mathrm{NTf}_{2}\right]$ (6). These two fragments readily rearrange to intermediates $\left[\left(\mathrm{PR}_{2} \mathrm{Ar}{ }^{\prime}\right) \mathrm{Au}\left(\mu-\eta^{1}: \eta^{2}-\mathrm{C} \equiv \mathrm{CH}\right) \mathrm{Pt}-\right.$ $\left.(\mathrm{H})\left(\mathrm{P}^{t} \mathrm{Bu}_{3}\right)_{2}\right]^{+}(\mathrm{A})$ that subsequently evolve to compounds 3 by rapid $\sigma, \pi$ isomerization of the bridging $\mu$-C $\equiv \mathrm{CR}$ unit. In experimental agreement, the reaction of independently synthesized $\left[\left(\mathrm{PMe}_{2} \mathrm{Ar}^{\mathrm{Dipp}} 2\right) \mathrm{Au}(\mathrm{C} \equiv \mathrm{CH})\right](\mathbf{5 b})$ and $\left[\mathrm{Pt}\left(\mathrm{P}^{t} \mathrm{Bu}_{3}\right)_{2} \mathrm{H}\right]$ $\left[\mathrm{NTf}_{2}\right]$ (6) rapidly yields complex $3 \mathbf{b}$. As mentioned above, this does not apply to compound $\mathbf{5 c}$, whose reaction with $\mathbf{6}$ resulted in a complex mixture of products that include decomposition into elemental gold. Nevertheless, the corresponding $\left[\left(\mathrm{PCyp}_{2} \mathrm{Ar}^{\mathrm{Xyl} 2}\right) \mathrm{Au}\left(\mu-\eta^{2}: \eta^{1}-\mathrm{C} \equiv \mathrm{CH}\right) \mathrm{Pt}(\mathrm{H})\left(\mathrm{P}^{t} \mathrm{Bu}_{3}\right)_{2}\right]^{+}(3 \mathrm{c})$ has not been detected during the bimetallic activation of acetylene. An alternative orthogonal mechanism involving the initial oxidative addition of acetylene over 2 , followed by cis-trans isomerization and coupling with $\mathbf{1}$, was ruled out on the basis of significantly higher overall activation barriers (see Figure S2).

Information on the activation of the simplest alkyne $\left(\mathrm{C}_{2} \mathrm{H}_{2}\right)$ by FLPs is rather scarce. ${ }^{12 a}$ For the sake of completeness and to better compare our results with prior studies on main-group FLPs, we decided to test other more commonly employed triply bonded hydrocarbons. With regard to internal alkynes, all our attempts to access bimetallic vinylenes were unsuccessful. Reactions of 1:2 pairs with diphenylacetylene, 2-butyne, and 1,4-diphenylbutadiyne did not result in the formation of any new species even under more forcing experimental conditions. At variance, addition of phenylacetylene to an equimolar mixture of 1 and 2 provided phosphine-dependent divergent outcomes derived from $\mathrm{C}(\mathrm{sp})-\mathrm{H}$ bond cleavage (Scheme 3 ). In parallel with acetylene activation with the more congested pairs based on $\mathbf{1 b}, \mathbf{c}$, the reaction of these systems with $\mathrm{PhC} \equiv \mathrm{CH}$ was also immediate. In contrast, while acetylene activation took up to 24 $\mathrm{h}$ for the nonfrustrated 1a:2 pair, the reaction was complete after around $15 \mathrm{~min}$ in the case of phenylacetylene.

The appearance of a distinctive low-frequency ${ }^{1} \mathrm{H}$ NMR resonance at around $-10 \mathrm{ppm}$ flanked by ${ }^{195} \mathrm{Pt}$ satellites $\left({ }^{1} J_{\mathrm{HPt}}=\right.$ $608 \mathrm{~Hz}, 1 \mathrm{a}: 2 ;{ }^{1} J_{\mathrm{HPt}}=533 \mathrm{~Hz}, \mathbf{1 b}: 2$ and $\left.1 \mathrm{c}: 2\right)$ prompted us to 
Scheme 3. Product Distribution from the Activation of Phenylacetylene by TMOFLP Pairs 1:2

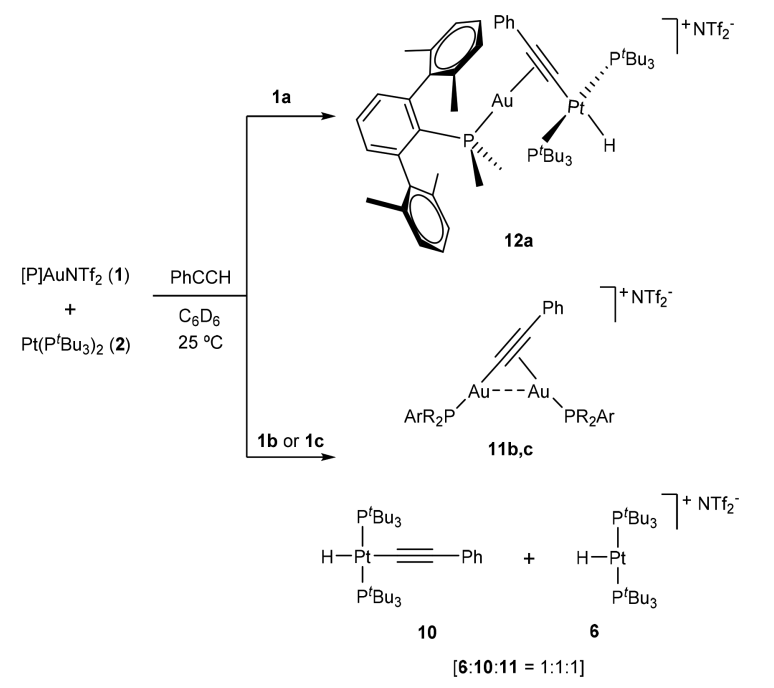

believe that corresponding heterobimetallic $\sigma, \pi$-acetylide complexes were formed in all cases. However, a more careful analysis revealed unexpected differences in product distribution for the less bulky terphenylphosphine $\mathrm{PMe}_{2} \mathrm{Ar}^{\mathrm{Xy} 12}$ in comparison to the more hindered systems (Scheme 3). Extracting the crude reaction mixtures with pentane permitted isolation of the same platinum-containing compound $\mathbf{1 0}$ for the pairs $\mathbf{1 b}: \mathbf{2}$ and $\mathbf{1 c}: \mathbf{2}$, while the less hindered gold fragment 1a did not led to any metallic species soluble in nonpolar hydrocarbon solvents. An infrared band at $2090 \mathrm{~cm}^{-1}$ was recorded for a Pt-hydride ligand in 10, while characteristic ${ }^{13} \mathrm{C}\left\{{ }^{1} \mathrm{H}\right\}$ NMR resonances at 118.8 and $117.6 \mathrm{ppm}$ accounted for a $\sigma$-bonded acetylide ligand. On the basis of these spectroscopic features and the high solubility, we proposed a molecular formulation for 10 as $\left[\mathrm{Pt}\left(\mathrm{P}^{t} \mathrm{Bu}_{3}\right)_{2}(\mathrm{H})\right.$ $(\mathrm{C} \equiv \mathrm{CPh})]$ : that is, the formal oxidative addition of phenylacetylene over $\mathrm{Pt}(0)$ compound 2 . This assumption was further corroborated by X-ray diffraction analysis (see Figure S3). Nevertheless, it is important to remark that compound $\mathbf{2}$ does not react with phenylacetylene even after longer reaction times $(48 \mathrm{~h})$ or at elevated temperatures $\left(80^{\circ} \mathrm{C}\right)$, which suggests a cooperative action between platinum and gold to account for alkyne $\mathrm{C}-\mathrm{H}$ activation.

The only detectable gold-containing species in these reactions were assigned to the corresponding bridging $\sigma, \pi$-acetylide digold complexes 11. Those where characterized by ${ }^{31} \mathrm{P}\left\{{ }^{1} \mathrm{H}\right\}$ NMR signals at $0.4(\mathbf{1 1 b})$ and 53.9 (11c), shifted to higher frequencies with respect to their precursors $\mathbf{1}$ (cf. -11.9 for $\mathbf{1 b}$ and $48.8 \mathrm{ppm}$ for $\mathbf{1 c}$ ), in agreement with other related examples. $^{24}$ Also similar to those results, the presence of a single ${ }^{31} \mathrm{P}$ resonance for each compound suggests rapid exchange of the $\sigma, \pi$ coordination in solution. ${ }^{18}$ However, the process is frozen in the solid state. An ORTEP representation of the molecular structure of $\mathbf{1 1} \mathbf{b}$ is shown in Figure $4 \mathrm{a}$. The $\sigma, \pi$ coordination of the acetylide is reflected by a nonsymmetric arrangement characterized by bond distances of 2.021(10) and 2.209(9) $\AA$ for the Au2-C1 and Au1-C1 bond distances, respectively. The Aul center is also connected to $\mathrm{C} 2$ by a slightly longer bond length of 2.310(9) A. The presence of an aurophilic interaction can be inferred from a Au1-Au2 distance of 3.366(1) $\AA$, which is faintly elongated in comparison to its related acetylide analogue $\left[\mathrm{Au}_{2}\{\mu-\mathrm{C} \equiv \mathrm{CH}\}\right]\left(d_{\mathrm{Au} 1-\mathrm{Au} 2}=3.31\right.$ $\AA)$, likely as a result of the higher steric pressure exerted by
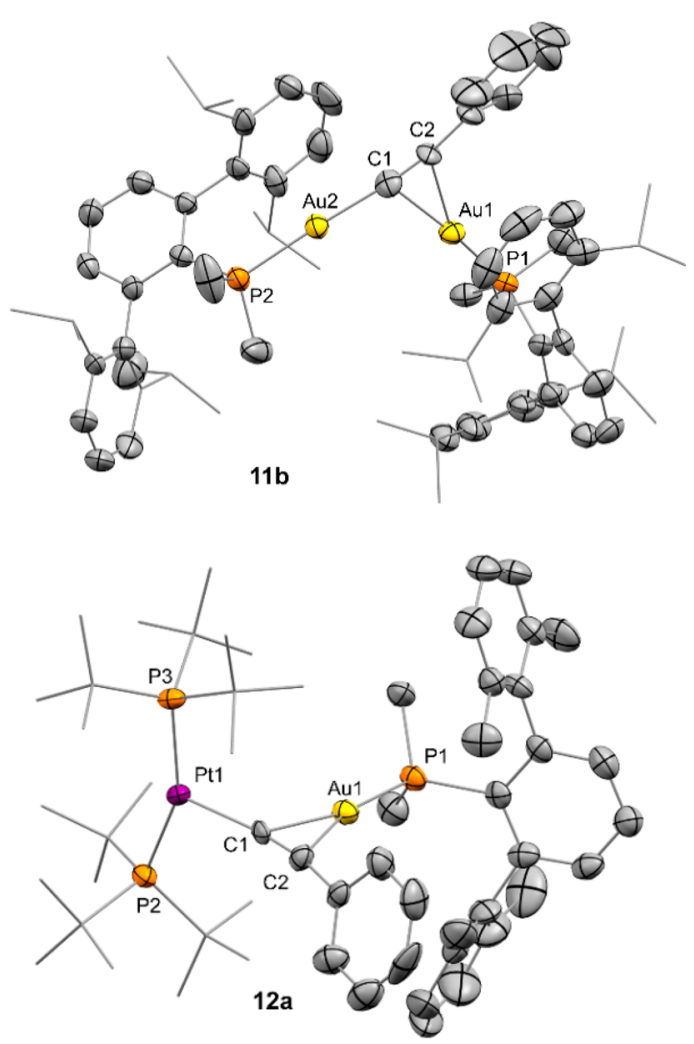

Figure 4. ORTEP diagrams of compounds $11 \mathbf{b}$ and 12a. For the sake of clarity hydrogen atoms, solvent molecules, and triflimide anions are excluded and some substituents have been represented in wireframe format, while thermal ellipsoids are set at 50\% probability. The hydride ligand bound to platinum in 12a could not be located in the Fourier electron density map.

phenylacetylide. Digold complexes $1 \mathbf{1 b}, \mathbf{c}$ were accompanied by equimolar amounts of $\left[\mathrm{Pt}\left(\mathrm{P}^{t} \mathrm{Bu}_{3}\right)_{2}(\mathrm{H})\right]^{+}(6)$ that could not be washed out with pentane, as evinced by a broad low-frequency ${ }^{1} \mathrm{H}$ NMR resonance at $1.16 \mathrm{ppm}\left({ }^{1} J_{\mathrm{PPt}}=6.5 \mathrm{~Hz}\right)$.

As noted earlier, the reaction of the less hindered 1a:2 pair with phenylacetylene yielded a divergent result. $\mathrm{C}(\mathrm{sp})-\mathrm{H}$ activation became evident by the presence of a distinctive hydridic ${ }^{1} \mathrm{H}$ NMR resonance at $-10.4 \mathrm{ppm}\left({ }^{2} J_{\mathrm{HP}}=14 \mathrm{~Hz},{ }^{1} J_{\mathrm{HPt}}=\right.$ $608 \mathrm{~Hz}$ ). However, a single platinum complex was formed in this case, which resonates at $82.2 \mathrm{ppm}\left({ }^{1} J_{\mathrm{PPt}}=2810 \mathrm{~Hz}\right)$ in its ${ }^{31} \mathrm{P}\left\{{ }^{1} \mathrm{H}\right\}$ NMR spectrum and could not be washed out using nonpolar hydrocarbon solvents. The corresponding $\mathrm{C} \equiv \mathrm{C}$ stretching frequency rendered an infrared band shifted to lower wavenumbers $\left(\nu_{\mathrm{C} \equiv \mathrm{C}} 1982 \mathrm{~cm}^{-1}\right.$; cf. $2048 \mathrm{~cm}^{-1}$ for $\mathbf{1 1 b}$, $2029 \mathrm{~cm}^{-1}$ for $11 \mathrm{c}$, and $2090 \mathrm{~cm}^{-1}$ for 10), while sp-hybridized carbon atoms render ${ }^{13} \mathrm{C}\left\{{ }^{1} \mathrm{H}\right\}$ NMR resonances at lower frequencies (91.1 and $85.9 \mathrm{ppm}$ ) in comparison to compounds $11 b, c$ and 10 (116-125 ppm). These observations expose the divergent product distribution derived from using phosphines with different steric profiles. Since the recorded parameters equate with heterobimetallic $\sigma, \pi$-acetylide compounds 3 , we assumed an analogous structure for this complex (12a), a premise that we could substantiate by X-ray diffraction analysis (Figure $4 \mathrm{~b}$ ). The bulkier nature of the phenylacetylide moiety with respect to the unsubstituted acetylide in $3 a$ is likely the cause of a more intense distortion of the $\mathrm{T}$-shaped platinum fragment, where a $\mathrm{P}-\mathrm{Pt}-\mathrm{P}$ angle of $156.71(8)^{\circ}$ is recorded (cf. $162.76(5)^{\circ}$ for $\left.3 a\right)$. The close proximity between the acetylide phenyl fragment and the ortho substituents of one of the flanking 
aryl rings of the terphenyl moiety may be responsible for the dissimilar product distributions found between $\mathrm{PMe}_{2} \mathrm{Ar}^{\mathrm{Xyl} 2}$ vs $\mathrm{PMe}_{2} \mathrm{Ar}^{\mathrm{Dipp}} / \mathrm{PCyp}_{2} \mathrm{Ar}^{\mathrm{Xyl2}}$.

On the basis of our experimental and computational studies on acetylene activation, initial formation of a gold-alkyne adduct like 9 seems most plausible. The slightly higher acidity of phenylacetylene, as well as its higher size, may account for the prevalence of the deprotonation pathway in detriment of the 1,2addition route toward vinylene structures, which were not detected. In turn, the dissimilar reaction products depicted in Scheme 3 might be understood on steric grounds. Thus, selective formation of compounds 11 for the bulkier $\mathrm{PMe}_{2} \mathrm{Ar}^{\mathrm{Dipp}}$ - $/ \mathrm{PCyp}_{2} \mathrm{Ar}^{\mathrm{Xyl} 2}$-based systems could be the result of a higher steric clash between the tert-butyl substituents on the platinum fragment and the terphenyl moiety of the gold-bound phosphine. In contrast, the reduced steric pressure introduced by $\mathrm{PMe}_{2} \mathrm{Ar}^{\mathrm{Xyl2}}$ may permit easier access to the heterobimetallic compound 12a, analogous to its unsubstituted acetylide version (3a).

We thought of interest to carry out several further experiments to shed some light into the operating cooperative mechanism. In the same manner as we observed for acetylene activation, the reactivity of the individual metallic fragments starkly contrasts with that of the bimetallic pairs. Accordingly, platinum compound 2 does not exhibit any reactivity toward phenylacetylene even after heating at $80{ }^{\circ} \mathrm{C}$ for $48 \mathrm{~h}$ (Scheme $4 \mathrm{a}$ ). In

\section{Scheme 4. Selected Experiments Carried out to Provide Information about the Mechanism of Phenylacetylene Activation Mediated by TMOFLPs 1:2}

(A)

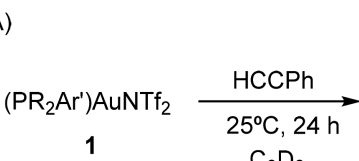
$\mathrm{C}_{6} \mathrm{D}_{6}$
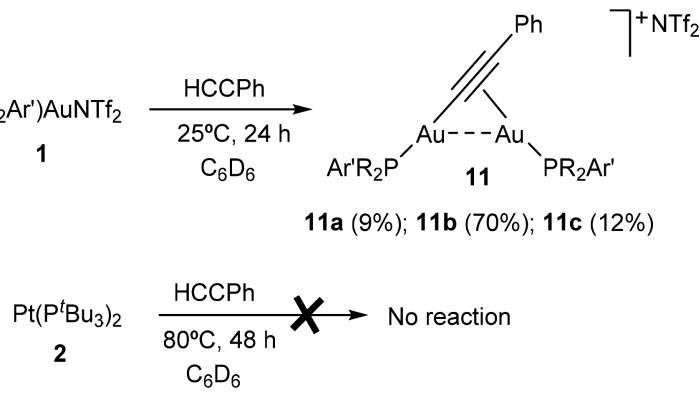

(B)
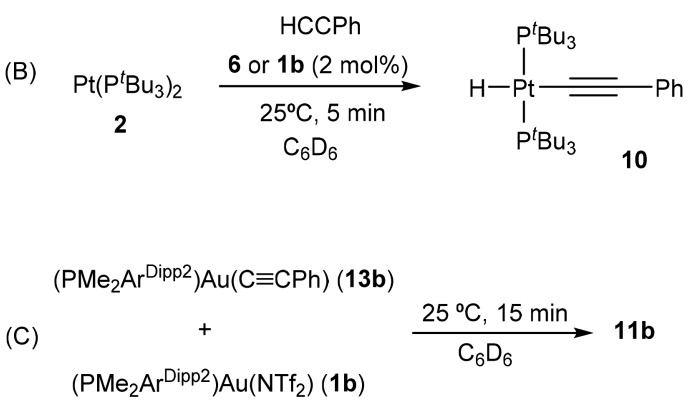

turn, compounds 1 promote $\mathrm{C}(\mathrm{sp})-\mathrm{H}$ cleavage of the alkyne to form the corresponding digold $\sigma, \pi$-acetylide complexes 11, but at a considerably slower pace $\left(24 \mathrm{~h}\right.$ at $25^{\circ} \mathrm{C}$ : $1 \mathrm{aa}, 9 \%$ of $\mathbf{1 1 a} ; \mathbf{1 b}$, $70 \%$ of $11 b$; 1c, $12 \%$ of 11 ; NMR spectroscopic yields). To account for the origin of $\mathbf{1 0}$, we performed the reaction of $\mathbf{2}$ with equivalent amounts of phenylacetylene and catalytic quantities of 1 . In addition, we also tested the same transformation but using $\mathbf{6}$ as the catalyst, since this presumably forms in situ after protonation of $\mathbf{2}$ by small amounts of $\mathrm{HNTf}_{2}$ derived from the reaction of 1 and phenylacetylene toward 11. Catalytic amounts of compound 6 may also derive from the cooperative $\mathrm{Au} / \mathrm{Pt}$ $\mathrm{C}(\mathrm{sp})-\mathrm{H}$ activation of phenylacetylene by a deprotonation mechanism. As anticipated, immediate conversion of $\mathbf{2}$ into $\mathbf{1 0}$ was observed at room temperature using either $\mathbf{1}$ or $\mathbf{6}$ in catalytic amounts as low as $2 \mathrm{~mol} \%$ (Scheme $4 \mathrm{~b}$ ). The reaction of the independently prepared $\mathbf{1 0}$ with $\mathbf{1 a}$ leads to $\mathbf{3 a}$ as the major species by NMR analysis, though other unidentified side products are also formed. The reaction of the independently synthesized neutral $\sigma$-acetylide compound $\left[\left(\mathrm{PMe}_{2} \mathrm{Ar}^{\mathrm{Dipp}}{ }^{2}\right) \mathrm{Au}-\right.$ $(\mathrm{C} \equiv \mathrm{CPh})]$ (13b; ORTEP diagram in Figure S4) with $\mathbf{1 b}$ yielded the expected digold $\sigma, \pi$-acetylide $\mathbf{1 1 b}$ under mild conditions (Scheme 4c). This result parallels the reactivity previously described for NHC-based gold complexes, where the latter transformation proceeds smoothly, ${ }^{24 \mathrm{f}}$ as also occurs with the parent unsubstituted acetylide $(\mathrm{C} \equiv \mathrm{CH})$ fragment. ${ }^{18}$ Thus, terminal acetylides of type $\mathbf{1 3}$ may be regarded as key intermediates toward compounds $\mathbf{1 1}$ during the activation of $\mathrm{PhCCH}$.

On consideration of all the information discussed above, Scheme 5 contains an overall mechanistic picture to account for the phosphine-dependent product distribution during the activation of alkynes. The common gold acetylene adduct 9 is proposed to be a key intermediate. While both deprotonation and 1,2-addition mechanisms (blue and red in Scheme 5, respectively) are viable for acetylene, only the deprotonation pathway seems to be operative in the case of the more acidic phenyl-substituted alkyne. Once the latter is deprotonated to form an equimolar mixture of $\mathbf{1 3}$ and $\mathbf{6}$, steric factors appear to dominate the final product distribution. The combination of the more hindered terphenylphosphines with the bulkier phenylacetylene prevents formation of the corresponding $\mathrm{Au} / \mathrm{Pt}$ heterobimetallic adducts likely due to a steric clash, while the latter is the only observed complex in the $\mathrm{PMe}_{2} \mathrm{Ar}^{\mathrm{Xyl2}}$ system. In turn, terminal gold acetylides 13 , although unable to react with $\left[\mathrm{Pt}\left(\mathrm{P}^{t} \mathrm{Bu}_{3}\right)_{2} \mathrm{H}\right]^{+}(6)$, rapidly yield the corresponding digold $\sigma, \pi$ acetylides 11 upon combination with still unreacted triflimide complexes 1. We can also infer from our experimental observations that several of the transformations depicted in Scheme 5 constitute dynamic equilibria that are dependent on reaction conditions.

\section{CONCLUSIONS}

In summary, we provide evidence for the potential of a cooperative $\mathrm{Au}(\mathrm{I}) / \mathrm{Pt}(0)$ bimetallic system that behaves as a metal-only frustrated Lewis pair for the activation of small molecules. We have demonstrated that subtle modifications of the phosphine ligands bound to gold have a strong effect on the regioselectivity of acetylene activation. Thus, simply by adjusting the steric hindrance of those phosphines, we have been able to select the operating mechanism (deprotonation vs 1,2-addition) during acetylene activation with full specificity. This is possible without the need to alter the basicity of the platinum(0) moiety, thus contrasting with main-group FLP systems. Moreover, ligand modification also permitted us to diverge from the product distribution that results from $\mathrm{C}-\mathrm{H}$ bond cleavage in phenylacetylene. While the less congested system based on $\mathrm{PMe}_{2} \mathrm{Ar}^{\mathrm{Xyl} 2}$ yields a heterobimetallic $\sigma, \pi$ acetylide compound, the more hindered pairs constructed around $\mathrm{PMe}_{2} \mathrm{Ar}^{\mathrm{Dipp} 2}$ and $\mathrm{PCyp}_{2} \mathrm{Ar}^{\mathrm{Xyl2}}$ resulted in the formation of equimolar mixtures of digold $\sigma, \pi$-acetylide compounds, $\left[\mathrm{Pt}\left(\mathrm{P}^{t} \mathrm{Bu}_{3}\right)_{2}(\mathrm{H})\right]^{+}$, and $\left[\mathrm{Pt}\left(\mathrm{P}^{t} \mathrm{Bu}_{3}\right)_{2}(\mathrm{H})(\mathrm{C} \equiv \mathrm{CPh})\right]$. These results highlight one of the advantages of incorporating 
Scheme 5. Overall Representation of the Proposed Pathways to Account for Product Distribution during Alkyne Activation

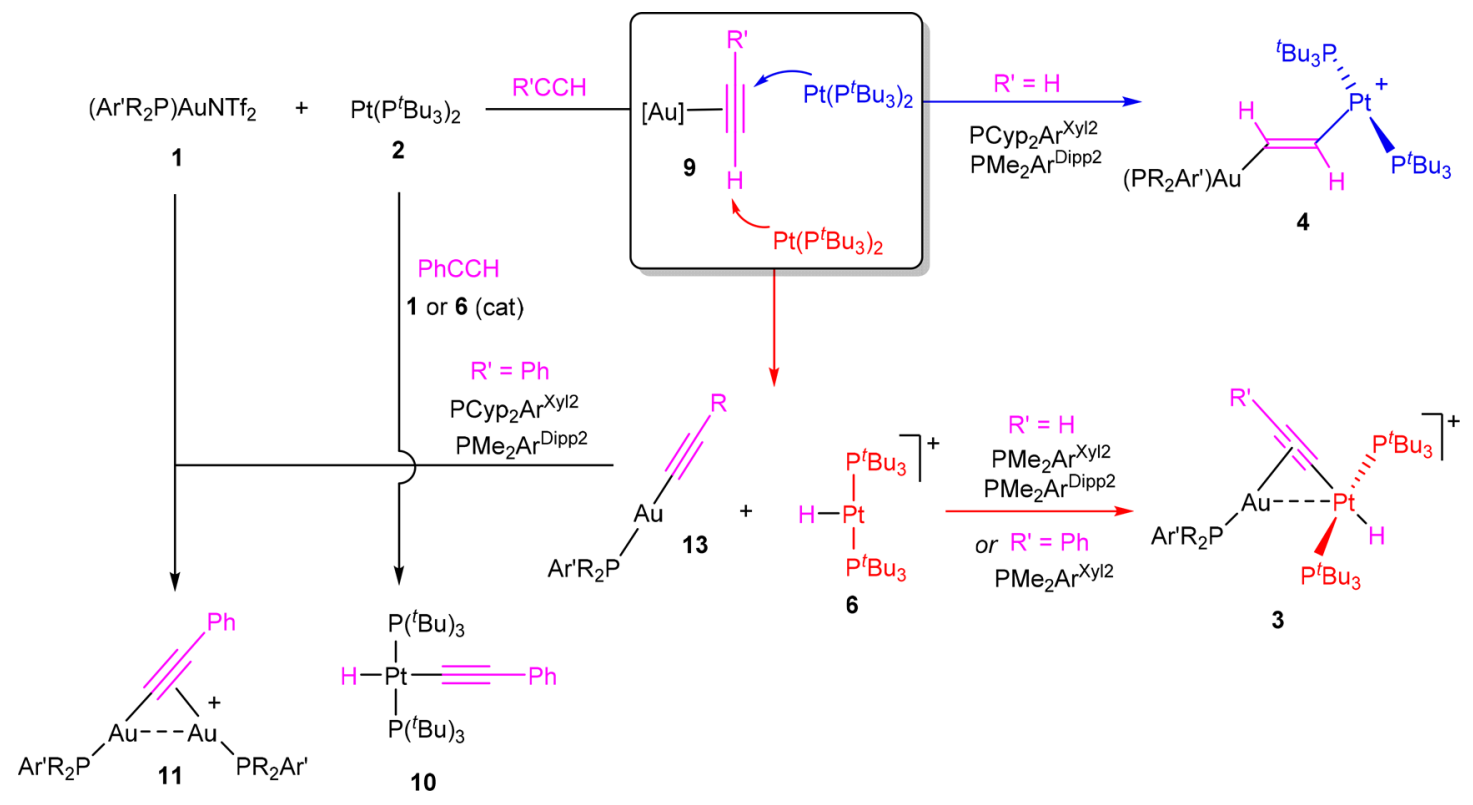

transition metals into frustrated designs, namely the ability to easily tune the stereoelectronic properties of the acidic site, in turn a challenging task in traditional FLPs that rely on the electrophilicity of fluorinated boranes. The straightforward control of these properties in TMFLPs may be exploited for the development of more selective catalytic transformations drawn on the concept of frustration.

\section{EXPERIMENTAL SECTION}

General Considerations. All preparations and manipulations were carried out using standard Schlenk and glovebox techniques, under an atmosphere of argon and of high-purity nitrogen, respectively. All solvents were dried, stored over $4 \AA$ molecular sieves, and degassed prior to use. Toluene $\left(\mathrm{C}_{7} \mathrm{H}_{8}\right)$ and $n$-pentane $\left(\mathrm{C}_{5} \mathrm{H}_{12}\right)$ were distilled under nitrogen over sodium. Tetrahydrofuran (THF) and diethyl ether were distilled under nitrogen over sodium/benzophenone. $\left[\mathrm{D}_{6}\right]$ Benzene was dried over molecular sieves $(4 \AA)$ and $\mathrm{CD}_{2} \mathrm{Cl}_{2}$ over $\mathrm{CaH}_{2}$ and distilled under argon. [AuCl(THT)] (THT = tetrahydrothiophene $)^{25}$ and compounds $\mathbf{1 a},{ }^{7} \mathbf{1 b},{ }^{18} \mathbf{1 c},{ }^{7} \mathbf{2}^{26}$ and $\mathbf{6}^{16}$ were prepared as described previously. Other chemicals were commercially available and were used as received. Solution NMR spectra were recorded on Bruker AMX-300, DRX-400, and DRX-500 spectrometers. Spectra were referenced to external $\mathrm{SiMe}_{4}(\delta 0 \mathrm{ppm})$ using the residual proton solvent peaks as internal standards ( ${ }^{1} \mathrm{H}$ NMR experiments) or the characteristic resonances of the solvent nuclei $\left({ }^{13} \mathrm{C}\right.$ NMR experiments), while ${ }^{31} \mathrm{P}$ was referenced to $\mathrm{H}_{3} \mathrm{PO}_{4}$. Spectral assignments were made by routine one- and two-dimensional NMR experiments where appropriate (Figure 5). Infrared spectra were recorded on a Bruker Vector 22 spectrometer, and sampling preparation was carried out in Nujol. For elemental analyses a LECO TruSpec CHN elementary analyzer was utilized. 1965525, 1965526, and 19865011986504 contain the supplementary crystallographic data for this paper. These data can be obtained free of charge from the Cambridge Crystallographic Data Centre.

$\left[\left(\mathrm{PMe}_{2} \mathrm{Ar}{ }^{\mathrm{Xyl2}}\right) \mathrm{Au}\left(\mu-\eta^{2}: \eta^{1}-\mathrm{C} \equiv \mathrm{CH}\right) \mathrm{Pt}(\mathrm{H})\left(\mathrm{P}^{t} \mathrm{Bu}_{3}\right)_{2}\right] \mathrm{NTf}_{2}(3 \mathrm{a})$. A solid mixture of $1 \mathrm{a}(100 \mathrm{mg}, 0.121 \mathrm{mmol})$ and $2(73 \mathrm{mg}, 0.121 \mathrm{mmol})$ was dissolved in $5 \mathrm{~mL}$ of toluene and stirred at room temperature for $12 \mathrm{~h}$ under a $\mathrm{C}_{2} \mathrm{H}_{2}$ atmosphere $(0.5 \mathrm{bar})$. The solution was layered with pentane $(10 \mathrm{~mL})$ and stored at $-30^{\circ} \mathrm{C}$ overnight to yield compound $3 \mathrm{a}$ as colorless crystals $(115 \mathrm{mg}, 66 \%)$. Anal. Calcd for $\mathrm{C}_{52} \mathrm{H}_{83} \mathrm{AuF}_{6} \mathrm{NO}_{4} \mathrm{P}_{3} \mathrm{PtS}_{2}: \mathrm{C}, 43.1 ; \mathrm{H}, 5.8 ; \mathrm{N}, 1.0 ; \mathrm{S}$, 4.4. Found: $\mathrm{C}$, $43.1 ; \mathrm{H}, 5.5 ; \mathrm{N}, 1.1 ; \mathrm{S}, 4.4 .{ }^{1} \mathrm{H}$ NMR $\left(400 \mathrm{MHz}, \mathrm{C}_{6} \mathrm{D}_{6}, 25^{\circ} \mathrm{C}\right): \delta 7.26(\mathrm{t}$, $\left.2 \mathrm{H},{ }^{3} J_{\mathrm{HH}}=7.6 \mathrm{~Hz}, \mathrm{H}_{\mathrm{b}}\right), 7.18\left(\mathrm{~m}, 1 \mathrm{H}, \mathrm{H}_{\mathrm{d}}\right), 7.15\left(\mathrm{~d}, 4 \mathrm{H},{ }^{3} \mathrm{~J}_{\mathrm{HH}}=7.6 \mathrm{~Hz}\right.$,

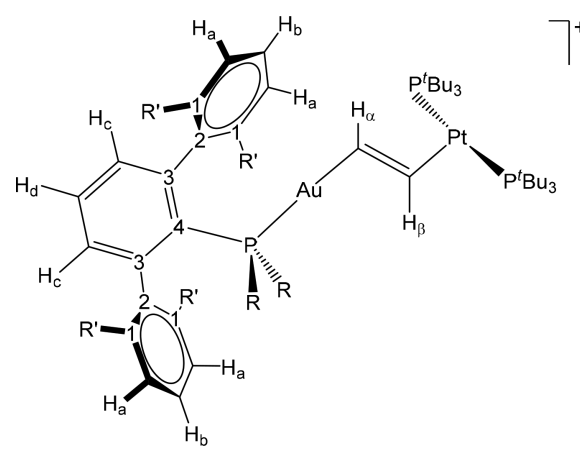

Figure 5. General labeling scheme used for ${ }^{1} \mathrm{H}$ and ${ }^{13} \mathrm{C}\left\{{ }^{1} \mathrm{H}\right\}$ NMR assignments.

$\left.\mathrm{H}_{\mathrm{a}}\right), 6.71\left(\mathrm{dd}, 2 \mathrm{H},{ }^{3} \mathrm{~J}_{\mathrm{HH}}=7.5 \mathrm{~Hz},{ }^{4} J_{\mathrm{HP}}=3.5 \mathrm{~Hz}, \mathrm{H}_{\mathrm{c}}\right), 2.98(\mathrm{~m}, 1 \mathrm{H}, \mathrm{C} \equiv$ $\mathrm{CH}), 2.15\left(\mathrm{~s}, 12 \mathrm{H}, \mathrm{Me}_{\mathrm{Xyl}}\right), 1.52\left(\mathrm{~d}, 6 \mathrm{H},{ }^{2} J_{\mathrm{HP}}=9.5 \mathrm{~Hz}, \mathrm{PMe}_{2}\right), 1.49$ (vt, $\left.54 \mathrm{H},{ }^{3} J_{\mathrm{HP}}=6.4 \mathrm{~Hz},{ }^{\mathrm{t}} \mathrm{Bu}\right),-10.27\left(\mathrm{~m}, 1 \mathrm{H},{ }^{2} J_{\mathrm{HP}}=14 \mathrm{~Hz},{ }^{1} J_{\mathrm{HPt}}=571 \mathrm{~Hz}\right.$, $\mathrm{Pt}-\mathrm{H}) .{ }^{13} \mathrm{C}\left\{{ }^{1} \mathrm{H}\right\}$ NMR $\left(100 \mathrm{MHz}, \mathrm{C}_{6} \mathrm{D}_{6}, 25^{\circ} \mathrm{C}\right): \delta 146.8\left(\mathrm{~d},{ }^{2} J_{\mathrm{CP}}=10\right.$ $\left.\mathrm{Hz}, \mathrm{C}_{3}\right), 141.1\left(\mathrm{~d},{ }^{3} J_{\mathrm{CP}}=4 \mathrm{~Hz}, \mathrm{C}_{2}\right), 136.8\left(\mathrm{C}_{1}\right), 132.4\left(\mathrm{CH}_{\mathrm{d}}\right), 131.4(\mathrm{~d}$, $\left.{ }^{3} J_{\mathrm{CP}}=8 \mathrm{~Hz}, \mathrm{CH}_{\mathrm{c}}\right), 129.3\left(\mathrm{CH}_{\mathrm{b}}\right), 128.8\left(\mathrm{CH}_{\mathrm{a}}\right), 127.4\left(\mathrm{~d},{ }^{1} J_{\mathrm{CP}}=57 \mathrm{~Hz}\right.$, $\left.\mathrm{C}_{4}\right), 126.6\left(\mathrm{~d},{ }^{2} J_{\mathrm{CP}}=79 \mathrm{~Hz}, \mathrm{C} \equiv \mathrm{CH}\right), 121.4\left(\mathrm{q},{ }^{1} J_{\mathrm{CF}}=323 \mathrm{~Hz}, \mathrm{CF}_{3}\right)$, $108.2\left(\mathrm{~d},{ }^{2} \mathrm{~J}_{\mathrm{CP}}=20 \mathrm{~Hz}, \mathrm{C} \equiv \mathrm{CH}\right), 41.2\left(\mathrm{vt},{ }^{1} \mathrm{~J}_{\mathrm{CP}}=8 \mathrm{~Hz}, \mathrm{Pt}-\mathrm{C}\left(\mathrm{CH}_{3}\right)_{3}\right)$, $33.1\left(\mathrm{Pt}-\left(\mathrm{C}\left(\mathrm{CH}_{3}\right)_{3}\right)\right), 21.8\left(\mathrm{Me}_{\mathrm{Xyl}}\right), 17.0\left(\mathrm{~d},{ }^{1} J_{\mathrm{CP}}=38 \mathrm{~Hz}, \mathrm{PMe}_{2}\right)$. ${ }^{31} \mathrm{P}\left\{{ }^{1} \mathrm{H}\right\}$ NMR $\left(160 \mathrm{MHz}, \mathrm{C}_{6} \mathrm{D}_{6}, 25{ }^{\circ} \mathrm{C}\right): \delta 82.9\left({ }^{1} J_{\mathrm{PPt}}=2768 \mathrm{~Hz}\right.$, $\left.\mathrm{P}\left({ }^{\mathrm{t}} \mathrm{Bu}\right)_{3}\right), 0.8$ (Au-P). IR (Nujol): $\nu(\equiv \mathrm{C}-\mathrm{H}) 3171, \nu(\mathrm{C} \equiv \mathrm{C}) 1843$ $\mathrm{cm}^{-1}$.

[(PCyp $\left.\left.\mathrm{Ar}^{\mathrm{Xyl2}}\right) \mathrm{Au}\left(\mu-\eta^{1}: \eta^{1}-\mathrm{HC}=\mathrm{CH}\right) \mathrm{Pt}\left(\mathrm{P}^{t} \mathrm{Bu}_{3}\right)_{2}\right] \mathrm{NTf}_{2}$ (4c). A mixture of compounds $1 \mathrm{c}(100 \mathrm{mg}, 0.107 \mathrm{mmol})$ and $2(64 \mathrm{mg}, 0.107$ $\mathrm{mmol}$ ) was dissolved in toluene $(5 \mathrm{~mL})$, and the argon atmosphere was replaced by $\mathrm{C}_{2} \mathrm{H}_{2}(0.5$ bar $)$, upon which the bright yellow solution changed to an intense orange. The solution was then filtered, layered with pentane, and stored at $-20^{\circ} \mathrm{C}$ overnight to yield compound $4 \mathrm{c}$ as orange crystals (68 mg, 41\%). Anal. Calcd for $\mathrm{C}_{60} \mathrm{H}_{95} \mathrm{AuF}_{6} \mathrm{NO}_{4} \mathrm{P}_{3} \mathrm{PtS}_{2}$ : C, 46.3; H, 6.1; N, 1.0; S, 4.1. Found: C, 45.9; H, 5.7; N, 1.0; S, 3.8. ${ }^{1} \mathrm{H}$ $\operatorname{NMR}\left(400 \mathrm{MHz}, \mathrm{C}_{6} \mathrm{D}_{6}, 25^{\circ} \mathrm{C}\right): \delta 7.19-7.08\left(\mathrm{~m}, 3 \mathrm{H}, \mathrm{H}_{\mathrm{b}}, \mathrm{H}_{\mathrm{d}}\right), 7.01(\mathrm{~d}$, $\left.4 \mathrm{H},{ }^{3} \mathrm{~J}_{\mathrm{HH}}=7.6 \mathrm{~Hz}, \mathrm{H}_{\mathrm{a}}\right), 6.66\left(\mathrm{dd}, 2 \mathrm{H},{ }^{3} J_{\mathrm{HH}}=7.7 \mathrm{~Hz},{ }^{4} J_{\mathrm{HP}}=2.7 \mathrm{~Hz}, \mathrm{H}_{\mathrm{c}}\right)$, $4.51\left(\mathrm{dt}, 1 \mathrm{H},{ }^{3} J_{\mathrm{HH}}=7.6 \mathrm{~Hz},{ }^{3} J_{\mathrm{HP}}=3.4 \mathrm{~Hz},{ }^{2} J_{\mathrm{HPt}}=110 \mathrm{~Hz}, \mathrm{H}_{\beta}\right), 4.20$ $\left(\mathrm{dd}, 1 \mathrm{H},{ }^{3} J_{\mathrm{HH}}=7.6 \mathrm{~Hz},{ }^{3} J_{\mathrm{HP}}=6.4 \mathrm{~Hz},{ }^{3} J_{\mathrm{HPt}}=194 \mathrm{~Hz}, \mathrm{H}_{\alpha}\right), 2.22-2.09$ (m, $2 \mathrm{H}, \mathrm{CH}), 1.97\left(\mathrm{~s}, 24 \mathrm{H}, \mathrm{Me}_{\mathrm{Xyl}}\right), 1.71-1.47\left(\mathrm{~m}, 12 \mathrm{H}, \mathrm{CH}_{2}\right), 1.36$ (vt, $\left.54 \mathrm{H},{ }^{3} J_{\mathrm{HP}}=6.5 \mathrm{~Hz},{ }^{\mathrm{t}} \mathrm{Bu}\right), 1.24-1.09\left(\mathrm{~m}, 4 \mathrm{H}, \mathrm{CH}_{2}\right) .{ }^{13} \mathrm{C}\left\{{ }^{1} \mathrm{H}\right\} \mathrm{NMR}$ $\left(100 \mathrm{MHz}, \mathrm{C}_{6} \mathrm{D}_{6}, 25^{\circ} \mathrm{C}\right): \delta 159.4\left(\mathrm{~d},{ }^{2} J_{\mathrm{CP}}=113,{ }^{1} J_{\mathrm{CH}}=198 \mathrm{~Hz}, \mathrm{CH}_{\alpha}\right)$, 
$148.9\left(\mathrm{~d},{ }^{2} J_{\mathrm{CP}}=10 \mathrm{~Hz}, \mathrm{C}_{3}\right), 142.4\left(\mathrm{~d},{ }^{3} J_{\mathrm{CP}}=5 \mathrm{~Hz}, \mathrm{C}_{2}\right), 137.9\left(\mathrm{C}_{1}\right)$, $137.0\left(\mathrm{~d},{ }^{3} J_{\mathrm{CP}}=6 \mathrm{~Hz}, \mathrm{CH}_{\mathrm{c}}\right), 132.4\left(\mathrm{~d},{ }^{4} J_{\mathrm{CP}}=8 \mathrm{~Hz}, \mathrm{CH}_{\mathrm{d}}\right), 131.6\left(\mathrm{~d},{ }^{1} J_{\mathrm{CP}}\right.$ $\left.=40 \mathrm{~Hz}, \mathrm{C}_{4}\right), 129.3\left(\mathrm{CH}_{\mathrm{a}}\right), 125.7\left(\mathrm{CH}_{\mathrm{b}}\right), 121.7\left(\mathrm{q},{ }^{1} \mathrm{~J}_{\mathrm{CF}}=322 \mathrm{~Hz}, \mathrm{CF}_{3}\right)$, $115.5\left(\mathrm{~d},{ }^{3} J_{\mathrm{CP}}=24,{ }^{1} J_{\mathrm{CH}}=193 \mathrm{~Hz}, \mathrm{CH}_{\beta}\right), 41.2\left(\mathrm{vt},{ }^{1} J_{\mathrm{CP}}=8 \mathrm{~Hz}, \mathrm{Pt}-\right.$ $\left.\mathrm{C}\left(\mathrm{CH}_{3}\right)_{3}\right), 38.0\left(\mathrm{~d},{ }^{1} J_{\mathrm{CP}}=28 \mathrm{~Hz}, \mathrm{PCH}\right), 35.0\left(\mathrm{~d},{ }^{2} J_{\mathrm{CP}}=10 \mathrm{~Hz}, \mathrm{CH}_{2}\right)$, $33.1\left(\mathrm{Pt}-\left(\mathrm{C}\left(\mathrm{CH}_{3}\right)_{3}\right)\right), 32.5\left(\mathrm{~d},{ }^{2} J_{\mathrm{CP}}=10 \mathrm{~Hz}, \mathrm{CH}_{2}\right), 26.0\left(\mathrm{~d},{ }^{2} J_{\mathrm{CP}}=10\right.$ $\left.\mathrm{Hz}, \mathrm{CH}_{2}\right), 25.7\left(\mathrm{~d},{ }^{2} J_{\mathrm{CP}}=10 \mathrm{~Hz}, \mathrm{CH}_{2}\right), 21.4\left(\mathrm{Me}_{\mathrm{Xy}}\right) .{ }^{31} \mathrm{P}\left\{{ }^{1} \mathrm{H}\right\} \mathrm{NMR}$ $\left(160 \mathrm{MHz}, \mathrm{C}_{6} \mathrm{D}_{6}, 25^{\circ} \mathrm{C}\right): \delta 70.6\left({ }^{1} J_{\mathrm{PPt}}=3323 \mathrm{~Hz}, \mathrm{P}\left({ }^{\mathrm{t}} \mathrm{Bu}\right)_{3}\right), 51.7\left({ }^{4} J_{\mathrm{PPt}}\right.$ $=277 \mathrm{~Hz}, \mathrm{Au}-\mathrm{P}) . \mathrm{IR}(\mathrm{Nujol}): \nu(=\mathrm{C}-\mathrm{H}) 3172, \nu(\mathrm{C}=\mathrm{C}) 1645 \mathrm{~cm}^{-1}$.

[(PCyp $\left.\left.A_{2}{ }^{X y l 2}\right) A u(C \equiv C H)\right](5 c)$. A suspension of $\left(\mathrm{PCyp}_{2} \mathrm{Ar}^{\mathrm{Xyl} 2}\right)$ $\mathrm{AuCl}^{7}(200 \mathrm{mg}, 0.29 \mathrm{mmol})$ in toluene $(10 \mathrm{~mL})$ was cooled to $-40^{\circ} \mathrm{C}$, and a toluene solution containing a small excess (1.2 equiv) of $\mathrm{Mg}(\mathrm{C} \equiv$ $\mathrm{CH}) \mathrm{Br}$ was added dropwise. The mixture was stirred for an additional 2 $\mathrm{h}$ at $-40{ }^{\circ} \mathrm{C}$. The volatiles were removed in vacuo, and the residue was extracted with pentane. Evaporation of the solvent led to compound $5 \mathrm{c}$ as a white powder ( $35 \mathrm{mg}, 18 \%$ ). Gold acetylides are potentially explosive and should be handled with caution. Anal. Calcd for $\mathrm{C}_{34} \mathrm{H}_{40} \mathrm{AuP}: \mathrm{C}, 60.4 ; \mathrm{H}, 6.0$. Found: $\mathrm{C}, 60.4 ; \mathrm{H}, 5.8 .{ }^{1} \mathrm{H}$ NMR (400 $\left.\mathrm{MHz}, \mathrm{C}_{6} \mathrm{D}_{6}, 25{ }^{\circ} \mathrm{C}\right): \delta 7.29\left(\mathrm{t}, 2 \mathrm{H},{ }^{3} \mathrm{~J}_{\mathrm{HH}}=7.6 \mathrm{~Hz}, \mathrm{H}_{\mathrm{b}}\right), 7.09(\mathrm{~d}, 4 \mathrm{H}$, $\left.{ }^{3} J_{\mathrm{HH}}=7.56 \mathrm{~Hz}, \mathrm{H}_{\mathrm{a}}\right), 6.94\left(\mathrm{td}, 1 \mathrm{H},{ }^{3} \mathrm{~J}_{\mathrm{HH}}=7.6 \mathrm{~Hz},{ }^{5} J_{\mathrm{HP}}=1.6 \mathrm{~Hz}, \mathrm{H}_{\mathrm{d}}\right)$, $6.64\left(\mathrm{dd}, 2 \mathrm{H},{ }^{3} J_{\mathrm{HH}}=7.6 \mathrm{~Hz},{ }^{4} J_{\mathrm{HP}}=2.7 \mathrm{~Hz}, \mathrm{H}_{\mathrm{c}}\right), 2.17-2.05(\mathrm{~m}, 2 \mathrm{H}$, $\mathrm{PCH}), 1.97\left(\mathrm{~s}, 12 \mathrm{H}, \mathrm{Me}_{\mathrm{Xyl}}\right), 1.78\left(\mathrm{~d}, 1 \mathrm{H},{ }^{4} J_{\mathrm{HP}}=5.5 \mathrm{~Hz}, \mathrm{AuC} \equiv \mathrm{CH}\right)$, 1.7-1.1 (m, $\left.16 \mathrm{H}, \mathrm{CH}_{2}\right) .{ }^{1} \mathrm{C}\left\{{ }^{1} \mathrm{H}\right\} \operatorname{NMR}\left(100 \mathrm{MHz}, \mathrm{C}_{6} \mathrm{D}_{6}, 25^{\circ} \mathrm{C}\right): \delta$ $148.8\left(\mathrm{~d},{ }^{2} J_{\mathrm{CP}}=10 \mathrm{~Hz}, \mathrm{C}_{3}\right), 141.9\left(\mathrm{~d},{ }^{3} J_{\mathrm{CP}}=5 \mathrm{~Hz}, \mathrm{C}_{2}\right), 136.3\left(\mathrm{C}_{1}\right)$, $132.0\left(\mathrm{~d},{ }^{3} J_{\mathrm{CP}}=7 \mathrm{~Hz}, \mathrm{CH}_{\mathrm{c}}\right), 130.8\left(\mathrm{~d},{ }^{4} J_{\mathrm{CP}}=5 \mathrm{~Hz}, \mathrm{CH}_{\mathrm{d}}\right), 130.2\left(\mathrm{~d},{ }^{2} J_{\mathrm{CP}}\right.$ $=158 \mathrm{~Hz}, \mathrm{AuC} \equiv \mathrm{CH}), 128.9\left(\mathrm{~d},{ }^{1} J_{\mathrm{CP}}=48 \mathrm{~Hz}, \mathrm{C}_{4}\right), 128.7\left(\mathrm{CH}_{\mathrm{b}}\right), 128.4$ $\left(\mathrm{CH}_{\mathrm{a}}\right), 86.6\left(\mathrm{~d},{ }^{3} J_{\mathrm{CP}}=25 \mathrm{~Hz},{ }^{1} J_{\mathrm{CH}}=233 \mathrm{~Hz}, \mathrm{AuC} \equiv \mathrm{CH}\right), 38.3\left(\mathrm{~d},{ }^{1} J_{\mathrm{CP}}\right.$ $=31 \mathrm{~Hz}, \mathrm{PCH}), 35.1\left(\mathrm{~d},{ }^{2} J_{\mathrm{CP}}=10 \mathrm{~Hz}, \mathrm{CH}_{2}\right), 32.4\left(\mathrm{~d},{ }^{2} \mathrm{~J}_{\mathrm{CP}}=10 \mathrm{~Hz}\right.$, $\left.\mathrm{CH}_{2}\right), 25.4\left(\mathrm{~d},{ }^{2} J_{\mathrm{CP}}=11 \mathrm{~Hz}, \mathrm{CH}_{2}\right), 25.3\left(\mathrm{~d},{ }^{2} J_{\mathrm{CP}}=13 \mathrm{~Hz}, \mathrm{CH}_{2}\right), 21.6$ $\left(\mathrm{Me}_{\mathrm{xyl}}\right) .{ }^{31} \mathrm{P}\left\{{ }^{1} \mathrm{H}\right\} \operatorname{NMR}\left(160 \mathrm{MHz}, \mathrm{C}_{6} \mathrm{D}_{6}, 25{ }^{\circ} \mathrm{C}\right): \delta$ 55.5. IR (Nujol): $\nu(\equiv \mathrm{C}-\mathrm{H}) 3286, \nu(\mathrm{C} \equiv \mathrm{C}) 1944 \mathrm{~cm}^{-1}$.

$\left[\mathrm{Pt}\left(\mathrm{P}^{t} \mathrm{Bu}_{3}\right)_{2}(\mathrm{H})(\mathrm{C} \equiv \mathrm{CPh})\right](10)$. A toluene $(5 \mathrm{~mL})$ solution of $\mathbf{2}(64$ $\mathrm{mg}, 0.107 \mathrm{mmol})$, phenylacetylene $(11 \mu \mathrm{L}, 0.107 \mathrm{mmol})$, and $1 \mathbf{b}$ or $1 \mathrm{c}$ $(2 \mathrm{mg}, 0.002 \mathrm{mmol}$ ) was stirred at room temperature for $15 \mathrm{~min}$. The volatiles were removed in vacuo, and the residue was extracted with pentane $(3 \times 5 \mathrm{~mL})$. Evaporation of the solvent yielded compound 10 as a colorless oil $(26 \mathrm{mg}, 35 \%)$. Suitable crystals for X-ray diffraction studies can be obtained by slow pentane evaporation at room temperature. Anal. Calcd for $\mathrm{C}_{32} \mathrm{H}_{60} \mathrm{P} \mathrm{P}_{2} \mathrm{Pt}$ : C, 54.8; $\mathrm{H}$, 8.6. Found: $\mathrm{C}$, 54.9; H, 8.4. ${ }^{1} \mathrm{H}$ NMR $\left(400 \mathrm{MHz}, \mathrm{C}_{6} \mathrm{D}_{6}, 25^{\circ} \mathrm{C}\right): \delta 7.64\left(\mathrm{~d}, 2 \mathrm{H},{ }^{3} J_{\mathrm{HH}}=\right.$ $\left.7.3 \mathrm{~Hz}, o-\mathrm{C}_{6} \mathrm{H}_{5}\right), 7.21\left(\mathrm{t}, 2 \mathrm{H},{ }^{3} \mathrm{~J}_{\mathrm{HH}}=8.2 \mathrm{~Hz}, m-\mathrm{C}_{6} \mathrm{H}_{5}\right), 7.02\left(\mathrm{t}, 1 \mathrm{H},{ }^{3} \mathrm{~J}_{\mathrm{HH}}\right.$ $\left.=7.3 \mathrm{~Hz}, p-\mathrm{C}_{6} \mathrm{H}_{5}\right), 1.58\left(\mathrm{vt}, 54 \mathrm{H},{ }^{3} J_{\mathrm{HP}}=6.3 \mathrm{~Hz},{ }^{\mathrm{t}} \mathrm{Bu}\right),-9.46(\mathrm{t}, 1 \mathrm{H}$, $\left.{ }^{2} J_{\mathrm{HP}}=15.4,{ }^{1} J_{\mathrm{HPt}}=532.9 \mathrm{~Hz}, \mathrm{Pt}-\mathrm{H}\right) \cdot{ }^{13} \mathrm{C}\left\{{ }^{1} \mathrm{H}\right\} \mathrm{NMR}\left(100 \mathrm{MHz}, \mathrm{C}_{6} \mathrm{D}_{6}\right.$, $\left.25^{\circ} \mathrm{C}\right): \delta 131.3$ (CH-Ar), 130.7 (CH-Ar), 129.3 (C-Ar), $124.2(\mathrm{CH}-$ $\mathrm{Ar}), 118.8(\mathrm{C} \equiv \mathrm{CPh}), 117.6(\mathrm{C} \equiv \mathrm{CPh}), 40.4\left(\mathrm{vt},{ }^{1} J_{\mathrm{CP}}=8 \mathrm{~Hz},{ }^{2} J_{\mathrm{CPt}}=\right.$ $35 \mathrm{~Hz}, \mathrm{Pt}-\mathrm{P}\left(\mathrm{C}\left(\mathrm{CH}_{3}\right)_{3}\right), 33.1\left(\mathrm{Pt}-\mathrm{P}\left(\mathrm{C}\left(\mathrm{CH}_{3}\right)_{3}\right) .{ }^{31} \mathrm{P}\left\{{ }^{1} \mathrm{H}\right\}\right.$ NMR $(160$ $\left.\mathrm{MHz}, \mathrm{C}_{6} \mathrm{D}_{6}, 25^{\circ} \mathrm{C}\right): \delta 81.3\left({ }^{1} J_{\mathrm{PPt}}=2880 \mathrm{~Hz}\right)$. IR (Nujol): $\nu(\mathrm{C} \equiv \mathrm{C})$ $2090 \mathrm{~cm}^{-1}$.

$\left[\left(\mathrm{PR}_{2} \mathrm{Ar}\right)_{2} \mathrm{Au}_{2}\left(\mu-\eta^{1}: \eta^{2}-\mathrm{C} \equiv \mathrm{CPh}\right)\right] \mathrm{NTf}_{2}$ (11). To a solution of compounds $1(100 \mathrm{mg}, 0.107 \mathrm{mmol})$ and $2(64 \mathrm{mg}, 0.107 \mathrm{mmol})$ in toluene $(5 \mathrm{~mL})$ was added 1 equiv of phenylacetylene $(11 \mu \mathrm{L}, 0.107$ $\mathrm{mmol}$ ) and the mixture stirred at room temperature for $15 \mathrm{~min}$. The volatiles were removed in vacuo, and the residue was washed with pentane $(3 \times 5 \mathrm{~mL})$. The resulting fine white powder $(60 \mathrm{mg}, 11 \mathbf{b} ; 65$ $\mathrm{mg}, 11 \mathrm{c})$ contains a mixture of compounds 11 and 6 , the latter of which could not be separated by common methods but whose spectroscopic features did not hamper full characterization of compounds 11. A single crystal of $11 \mathbf{b}$ suitable for X-ray diffraction studies was grown by slow diffusion of pentane into a toluenes solution $(2: 1 \mathrm{v} / \mathrm{v})$ at $-30{ }^{\circ} \mathrm{C}$. Alternatively, compound $11 \mathrm{~b}$ could be synthesized free of 6 : to a solution of $\mathbf{1 b}(100 \mathrm{mg}, 0.107 \mathrm{mmol})$ in toluene $(5 \mathrm{~mL})$ was added 1 equiv of phenylacetylene $(11 \mu \mathrm{L}, 0.107 \mathrm{mmol})$ and the mixture stirred at room temperature for $18 \mathrm{~h}$. The volatiles were removed in vacuo, and the residue was washed with pentane $(3 \times 5 \mathrm{~mL})$ to yield $11 \mathbf{b}$ as a white powder $(90 \mathrm{mg}, 50 \%)$. Data for compound $11 \mathbf{b}$ are as follows. ${ }^{1} \mathrm{H}$ NMR $\left(400 \mathrm{MHz}, \mathrm{C}_{6} \mathrm{D}_{6}, 25^{\circ} \mathrm{C}\right): \delta 7.55\left(\mathrm{~d}, 2 \mathrm{H},{ }^{3} \mathrm{~J}_{\mathrm{HH}}=7.6 \mathrm{~Hz}, o-\mathrm{C}_{6} \mathrm{H}_{5}\right), 7.35$ $\left(\mathrm{m}, 2 \mathrm{H}, m-\mathrm{C}_{6} \mathrm{H}_{5}\right), 7.26\left(\mathrm{t}, 4 \mathrm{H},{ }^{3} J_{\mathrm{HH}}=7.6 \mathrm{~Hz}, \mathrm{H}_{\mathrm{b}}\right), 7.09\left(\mathrm{~d}, 8 \mathrm{H},{ }^{3} J_{\mathrm{HH}}=\right.$ $\left.7.8 \mathrm{~Hz}, \mathrm{H}_{\mathrm{a}}\right), 7.02\left(\mathrm{t}, 1 \mathrm{H},{ }^{3} \mathrm{~J}_{\mathrm{HH}}=8.4 \mathrm{~Hz}, p-\mathrm{C}_{6} \mathrm{H}_{5}\right), 6.93\left(\mathrm{~m}, 6 \mathrm{H}, \mathrm{H}_{\mathrm{c}} \mathrm{H}_{\mathrm{d}}\right)$, $2.54\left(\right.$ sept, $\left.8 \mathrm{H},{ }^{3} \mathrm{~J}_{\mathrm{HH}}=6.7 \mathrm{~Hz},{ }^{\mathrm{i}} \operatorname{Pr}(\mathrm{CH})\right), 1.57\left(\mathrm{~d}, 12 \mathrm{H},{ }^{2} \mathrm{~J}_{\mathrm{HP}}=9.8 \mathrm{~Hz}\right.$, $\left.\mathrm{PMe}_{2}\right), 1.29\left(\mathrm{~d}, 24 \mathrm{H},{ }^{3} \mathrm{~J}_{\mathrm{HH}}=6.7 \mathrm{~Hz},{ }^{\mathrm{i}} \operatorname{Pr}\left(\mathrm{CH}_{3}\right)\right), 0.90\left(\mathrm{~d}, 24 \mathrm{H},{ }^{3} \mathrm{~J}_{\mathrm{HH}}=\right.$ $\left.6.7 \mathrm{~Hz},{ }^{\mathrm{i}} \operatorname{Pr}\left(\mathrm{CH}_{3}\right)\right) .{ }^{13} \mathrm{C}\left\{{ }^{1} \mathrm{H}\right\}$ NMR $\left(100 \mathrm{MHz}, \mathrm{C}_{6} \mathrm{D}_{6}, 25{ }^{\circ} \mathrm{C}\right): \delta 146.6$ $\left(\mathrm{C}_{1}\right), 146.0\left(\mathrm{~d},{ }^{2} J_{\mathrm{CP}}=10 \mathrm{~Hz}, \mathrm{C}_{3}\right), 138.6\left(\mathrm{~d},{ }^{5} J_{\mathrm{CP}}=3 \mathrm{~Hz}, \mathrm{C}_{2}\right), 134.5(\mathrm{~d}$, $\left.{ }^{3} J_{\mathrm{CP}}=9 \mathrm{~Hz}, \mathrm{CH}_{\mathrm{c}}\right), 133.0(\mathrm{CH}-\mathrm{Ar}), 131.5\left(\mathrm{~d},{ }^{1} \mathrm{~J}_{\mathrm{CP}}=43 \mathrm{~Hz}, \mathrm{C}_{4}\right), 130.7$ (CH-Ar), $130.1\left(\mathrm{CH}_{\mathrm{b}}\right), 129.7(\mathrm{C}-\mathrm{Ar}), 129.3\left(\mathrm{CH}_{\mathrm{d}}\right), 125.7(\mathrm{CH}-\mathrm{Ar})$, $124.0\left(\mathrm{CH}_{\mathrm{a}}\right), 120.9\left(\mathrm{q},{ }^{1} J_{\mathrm{CF}}=323 \mathrm{~Hz}, \mathrm{CF}_{3}\right), 119.9(\mathrm{C} \equiv \mathrm{CPh}), 116.4$ $(\mathrm{C} \equiv \mathrm{CPh}), 31.6\left({ }^{\mathrm{i}} \operatorname{Pr}(\mathrm{CH}), 25.5\left({ }^{\mathrm{i}} \operatorname{Pr}\left(\mathrm{CH}_{3}\right), 23.1{ }^{\mathrm{i}} \operatorname{Pr}\left(\mathrm{CH}_{3}\right), 17.2(\mathrm{~d}\right.\right.$, $\left.{ }^{1} J_{\mathrm{CP}}=38 \mathrm{~Hz}, \mathrm{PMe}_{2}\right) \cdot{ }^{31} \mathrm{P}\left\{{ }^{1} \mathrm{H}\right\} \mathrm{NMR}\left(160 \mathrm{MHz}, \mathrm{C}_{6} \mathrm{D}_{6}, 25^{\circ} \mathrm{C}\right): \delta 0.4$. IR (Nujol): $\nu(\mathrm{C} \equiv \mathrm{C}) 2048 \mathrm{~cm}^{-1}$. Data for compound $11 \mathrm{c}$ are as follows. ${ }^{1} \mathrm{H}$ NMR $\left(400 \mathrm{MHz}, \mathrm{C}_{6} \mathrm{D}_{6}, 25{ }^{\circ} \mathrm{C}\right): \delta 7.42\left(\mathrm{~d}, 2 \mathrm{H},{ }^{3} J_{\mathrm{HH}}=8 \mathrm{~Hz}, o-\right.$ $\left.\mathrm{C}_{6} \mathrm{H}_{5}\right), 7.24\left(\mathrm{t}, 4 \mathrm{H},{ }^{3} J_{\mathrm{HH}}=7.6 \mathrm{~Hz}, \mathrm{H}_{\mathrm{b}}\right), 7.08\left(\mathrm{~d}, 8 \mathrm{H},{ }^{3} J_{\mathrm{HH}}=7.6 \mathrm{~Hz}, \mathrm{H}_{\mathrm{a}}\right)$, $7.05\left(\mathrm{~m}, 5 \mathrm{H},{ }^{3} \mathrm{~J}_{\mathrm{HH}}=7.6 \mathrm{~Hz}, \mathrm{H}_{\mathrm{d}}, m-\mathrm{C}_{6} \mathrm{H}_{5,} p-\mathrm{C}_{6} \mathrm{H}_{5}\right), 6.63\left(\mathrm{dd}, 4 \mathrm{H},{ }^{3} \mathrm{~J}_{\mathrm{HH}}=\right.$ $\left.7.6 \mathrm{~Hz},{ }^{4} J_{\mathrm{HP}}=3.3 \mathrm{~Hz}, \mathrm{H}_{\mathrm{c}}\right), 1.94\left(\mathrm{~s}, 24 \mathrm{H}, \mathrm{Me}_{\mathrm{Xyl}}\right), 2.25-2.13(\mathrm{~m}, 4 \mathrm{H}$, PCH $), 1.87-1.22\left(\mathrm{~m}, 32 \mathrm{H}, \mathrm{CH}_{2}\right) .{ }^{13} \mathrm{C}\left\{{ }^{1} \mathrm{H}\right\} \mathrm{NMR}\left(100 \mathrm{MHz}, \mathrm{C}_{6} \mathrm{D}_{6}, 25\right.$ $\left.{ }^{\circ} \mathrm{C}\right): \delta 148.1\left(\mathrm{~d},{ }^{2} J_{\mathrm{CP}}=10 \mathrm{~Hz}, \mathrm{C}_{3}\right), 141.5\left(\mathrm{~d},{ }^{3} J_{\mathrm{CP}}=5 \mathrm{~Hz}, \mathrm{C}_{2}\right), 136.8$ $\left(\mathrm{C}_{1}\right), 133.6\left(\mathrm{~d},{ }^{3} \mathrm{~J}_{\mathrm{CP}}=7 \mathrm{~Hz}, \mathrm{CH}_{\mathrm{c}}\right), 132.5\left(\mathrm{~d},{ }^{4} \mathrm{~J}_{\mathrm{CP}}=2 \mathrm{~Hz}, \mathrm{CH}_{\mathrm{d}}\right), 131.9$ (CH-Ar), 130.6 (CH-Ar), $129.3\left(\mathrm{CH}_{\mathrm{b}}\right), 129.1\left(\mathrm{CH}_{\mathrm{a}}\right), 128.8(\mathrm{C}-\mathrm{Ar})$, $126.5\left(\mathrm{~d},{ }^{1} J_{\mathrm{CP}}=46 \mathrm{~Hz}, \mathrm{C}_{4}\right), 125.7(\mathrm{CH}-\mathrm{Ar}), 124.2(\mathrm{C} \equiv \mathrm{CPh}), 121.6$ $(\mathrm{C} \equiv \mathrm{CPh}), 120.1\left(\mathrm{q},{ }^{1} J_{\mathrm{CF}}=323 \mathrm{~Hz}, \mathrm{CF}_{3}\right), 40.2\left(\mathrm{~d},{ }^{1} J_{\mathrm{CP}}=36 \mathrm{~Hz}, \mathrm{PCH}\right)$, $38.7\left(\mathrm{~d},{ }^{3} J_{\mathrm{CP}}=7 \mathrm{~Hz}, \mathrm{CH}_{2}\right), 38.4\left(\mathrm{~d},{ }^{3} J_{\mathrm{CP}}=6.6 \mathrm{~Hz}, \mathrm{CH}_{2}\right), 35.8\left(\mathrm{~d},{ }^{2} J_{\mathrm{CP}}=\right.$ $\left.12 \mathrm{~Hz}, \mathrm{CH}_{2}\right), 32.9\left(\mathrm{~d},{ }^{2} J_{\mathrm{CP}}=13 \mathrm{~Hz}, \mathrm{CH}_{2}\right), 21.6\left(\mathrm{Me}_{\mathrm{Xyl}}\right) .{ }^{31} \mathrm{P}\left\{{ }^{1} \mathrm{H}\right\} \mathrm{NMR}$ $\left(160 \mathrm{MHz}, \mathrm{C}_{6} \mathrm{D}_{6}, 25^{\circ} \mathrm{C}\right): \delta 53.9$. IR (Nujol): $\nu(\mathrm{C} \equiv \mathrm{C}) 2029 \mathrm{~cm}^{-1}$.

$\left[\left(\mathrm{PMe}_{2} \mathrm{Ar}^{\mathrm{Xyl}}\right) \mathrm{Au}\left(\mu-\eta^{2}: \eta^{1}-\mathrm{C} \equiv \mathrm{CPh}\right) \mathrm{Pt}(\mathrm{H})\left(\mathrm{P}^{t} \mathrm{Bu}_{3}\right)_{2}\right] \mathrm{NTf}_{2} \quad$ (12a). To a solution of $1 \mathrm{a}(100 \mathrm{mg}, 0.121 \mathrm{mmol})$ and $2(73 \mathrm{mg}, 0.121 \mathrm{mmol})$ in toluene $(5 \mathrm{~mL})$ was added 1 equiv of phenylacetylene $(13 \mu \mathrm{L}, 0.121$ $\mathrm{mmol}$ ) and the mixture stirred at room temperature for $15 \mathrm{~min}$. The volatiles were removed in vacuo, and the residue was washed with pentane $(3 \times 5 \mathrm{~mL})$ to yield compound $12 \mathrm{a}$ as a white powder $(70 \mathrm{mg}$, $38 \%$ ). Anal. Calcd for $\mathrm{C}_{58} \mathrm{H}_{87} \mathrm{AuF}_{6} \mathrm{NO}_{4} \mathrm{P}_{3} \mathrm{PtS}_{2}: \mathrm{C}, 45.7 ; \mathrm{H}, 5.8 ; \mathrm{N}, 0.9$; $\mathrm{S}$, 4.2. Found: C, 45.9; H, 5.6; N, 1.1; S, 4.3. ${ }^{1} \mathrm{H}$ NMR ( $400 \mathrm{MHz}, \mathrm{C}_{6} \mathrm{D}_{6}$, $\left.25^{\circ} \mathrm{C}\right): \delta 7.39\left(\mathrm{~d}, 2 \mathrm{H},{ }^{3} J_{\mathrm{HH}}=7.3 \mathrm{~Hz}, o-\mathrm{C}_{6} \mathrm{H}_{5}\right), 7.15\left(\mathrm{~m}, 3 \mathrm{H}, m-\mathrm{C}_{6} \mathrm{H}_{5}, p-\right.$ $\left.\mathrm{C}_{6} \mathrm{H}_{5}\right), 7.09\left(\mathrm{~m}, 5 \mathrm{H}, \mathrm{H}_{\mathrm{b}}, \mathrm{H}_{\mathrm{d}}\right), 6.99\left(\mathrm{~d}, 4 \mathrm{H},{ }^{3} J_{\mathrm{HH}}=7.6 \mathrm{~Hz}, \mathrm{H}_{\mathrm{a}}\right), 6.58(\mathrm{dd}$, $\left.2 \mathrm{H},{ }^{3} J_{\mathrm{HH}}=7.6 \mathrm{~Hz},{ }^{4} J_{\mathrm{HP}}=3.3 \mathrm{~Hz}, \mathrm{H}_{\mathrm{c}}\right), 2.06\left(\mathrm{~s}, 12 \mathrm{H}, \mathrm{Me}_{\mathrm{Xyl}}\right), 1.38(\mathrm{vt}, 54$ $\left.\mathrm{H},{ }^{3} J_{\mathrm{HP}}=6.3 \mathrm{~Hz},{ }^{\mathrm{t}} \mathrm{Bu}\right), 1.33\left(\mathrm{~d}, 6 \mathrm{H},{ }^{2} J_{\mathrm{HP}}=10 \mathrm{~Hz}, \mathrm{PMe}_{2}\right),-10.40(\mathrm{~m}$, $\left.1 \mathrm{H},{ }^{2} J_{\mathrm{HP}}=14 \mathrm{~Hz},{ }^{1} J_{\mathrm{HPt}}=608 \mathrm{~Hz}, \mathrm{Pt}-\mathrm{H}\right) \cdot{ }^{13} \mathrm{C}\left\{{ }^{1} \mathrm{H}\right\} \mathrm{NMR}(100 \mathrm{MHz}$, $\left.\mathrm{C}_{6} \mathrm{D}_{6}, 25^{\circ} \mathrm{C}\right): \delta 145.9\left(\mathrm{~d},{ }^{2} J_{\mathrm{CP}}=10 \mathrm{~Hz}, \mathrm{C}_{3}\right), 140.5\left(\mathrm{~d},{ }^{3} J_{\mathrm{CP}}=4 \mathrm{~Hz}, \mathrm{C}_{2}\right)$, $137.9\left(\mathrm{C}_{1}\right), 136.6(\mathrm{CH}-\mathrm{Ar}), 132.2\left(\mathrm{~d},{ }^{4} \mathrm{~J}_{\mathrm{CP}}=2 \mathrm{~Hz}, \mathrm{CH}_{\mathrm{d}}\right), 131.2(\mathrm{CH}-$ $\mathrm{Ar}), 129.3\left(\mathrm{~d},{ }^{3} J_{\mathrm{CP}}=9 \mathrm{~Hz}, \mathrm{CH}_{\mathrm{c}}\right), 129.2(\mathrm{C}-\mathrm{Ar}), 128.9\left(\mathrm{CH}_{\mathrm{b}}\right), 128.6$ $\left(\mathrm{CH}_{\mathrm{a}}\right), 125.7\left(\mathrm{~d},{ }^{1} J_{\mathrm{CP}}=60 \mathrm{~Hz}, \mathrm{C}_{4}\right), 124.2(\mathrm{CH}-\mathrm{Ar}), 121.3\left(\mathrm{q},{ }^{1} J_{\mathrm{CF}}=323\right.$ $\left.\mathrm{Hz}, \mathrm{CF}_{3}\right), 91.1(\mathrm{C} \equiv \mathrm{CPh}), 85.9(\mathrm{C} \equiv \mathrm{CPh}), 41.0\left(\mathrm{vt},{ }^{1} J_{\mathrm{CP}}=8 \mathrm{~Hz},{ }^{2} J_{\mathrm{CPt}}\right.$ $=35 \mathrm{~Hz}, \mathrm{Pt}-\mathrm{P}\left(\mathrm{C}\left(\mathrm{CH}_{3}\right)_{3}\right), 33.1\left(\mathrm{Pt}-\mathrm{P}\left(\mathrm{C}\left(\mathrm{CH}_{3}\right)_{3}\right), 32.2\left(\mathrm{Me}_{\mathrm{Xyl}}\right), 21.9(\mathrm{~d}\right.$, $\left.{ }^{1} J_{\mathrm{CP}}=36 \mathrm{~Hz}, \mathrm{PMe}_{2}\right) .{ }^{31} \mathrm{P}\left\{{ }^{1} \mathrm{H}\right\}$ NMR $\left(160 \mathrm{MHz}, \mathrm{C}_{6} \mathrm{D}_{6}, 25{ }^{\circ} \mathrm{C}\right): \delta 82.2$ $\left({ }^{1} J_{\mathrm{PPt}_{\mathrm{t}}}=2810 \mathrm{~Hz}, \mathrm{P}\left({ }^{\mathrm{t}} \mathrm{Bu}\right)_{3}\right), 3.3(\mathrm{Au}-\mathrm{P}) . \mathrm{IR}(\mathrm{Nujol}): \nu(\mathrm{C} \equiv \mathrm{C}) 1982$ $\mathrm{cm}^{-1}$.

[(PMe $\left.\left.{ }_{2} \mathrm{Ar}^{\mathrm{Dipp} 2}\right) \mathrm{Au}(\mathrm{C} \equiv \mathrm{CPh})\right]$ (13b). Following a previously reported method, ${ }^{27}$ to a solution of phenylacetylene $(36 \mu \mathrm{L}, 0.325 \mathrm{mmol})$ and $\mathrm{KOH}(18 \mathrm{mg}, 0.325 \mathrm{mmol})$ in $15 \mathrm{~mL}$ of methanol was added a suspension of $\left(\mathrm{PMe}_{2} \mathrm{Ar}^{\mathrm{Dipp}}\right) \mathrm{AuCl}(150 \mathrm{mg}, 0.216 \mathrm{mmol})$. The solution was stirred for $20 \mathrm{~h}$ at room temperature, and the solid was filtered and washed with diethyl ether $(2 \times 5 \mathrm{~mL})$ to yield compound $13 \mathbf{b}$ as a white solid (139 mg, 85\%). Gold acetylides are potentially explosive and should be handled with caution. Anal. Calcd for $\mathrm{C}_{40} \mathrm{H}_{48} \mathrm{AuP}: \mathrm{C}, 63.5 ; \mathrm{H}$, 6.4. Found: C, 63.2; $\mathrm{H}, 6.7 .{ }^{1} \mathrm{H}$ NMR $\left(400 \mathrm{MHz}, \mathrm{C}_{6} \mathrm{D}_{6}, 25^{\circ} \mathrm{C}\right): \delta 7.74$ $\left(\mathrm{d}, 2 \mathrm{H},{ }^{3} \mathrm{~J}_{\mathrm{HH}}=7.3 \mathrm{~Hz}, o-\mathrm{C}_{6} \mathrm{H}_{5}\right), 7.36\left(\mathrm{t}, 2 \mathrm{H},{ }^{3} \mathrm{~J}_{\mathrm{HH}}=7.8 \mathrm{~Hz}, m-\mathrm{C}_{6} \mathrm{H}_{5}\right)$, $7.17\left(\mathrm{~d}, 4 \mathrm{H},{ }^{3} J_{\mathrm{HH}}=7.8 \mathrm{~Hz}, \mathrm{H}_{\mathrm{a}}\right), 7.06\left(\mathrm{t}, 1 \mathrm{H},{ }^{3} \mathrm{~J}_{\mathrm{HH}}=8.3 \mathrm{~Hz}, p-\mathrm{C}_{6} \mathrm{H}_{5}\right)$, $6.99\left(\mathrm{~m}, 5 \mathrm{H}, \mathrm{H}_{\mathrm{b}}, \mathrm{H}_{\mathrm{c}}, \mathrm{H}_{\mathrm{d}}\right), 2.64\left(\mathrm{sept}, 4 \mathrm{H},{ }^{3} \mathrm{~J}_{\mathrm{HH}}=6.5 \mathrm{~Hz},{ }^{\mathrm{i}} \operatorname{Pr}(\mathrm{CH})\right)$, $1.34\left(\mathrm{~d}, 12 \mathrm{H},{ }^{3} J_{\mathrm{HH}}=6.5 \mathrm{~Hz},{ }^{\mathrm{i}} \operatorname{Pr}\left(\mathrm{CH}_{3}\right)\right), 0.92\left(\mathrm{~d}, 12 \mathrm{H},{ }^{3} J_{\mathrm{HH}}=6.5 \mathrm{~Hz}\right.$, $\left.{ }^{\mathrm{i}} \operatorname{Pr}\left(\mathrm{CH}_{3}\right)\right), 0.90\left(\mathrm{~d}, 6 \mathrm{H},{ }^{2} \mathrm{~J}_{\mathrm{HP}}=10 \mathrm{~Hz}, \mathrm{PMe}_{2}\right) .{ }^{13} \mathrm{C}\left\{{ }^{1} \mathrm{H}\right\}$ NMR $(100$ $\left.\mathrm{MHz}, \mathrm{C}_{6} \mathrm{D}_{6}, 25^{\circ} \mathrm{C}\right): \delta 146.6(\mathrm{CH}-\mathrm{Ar}), 145.7\left(\mathrm{~d},{ }^{2} J_{\mathrm{CP}}=11 \mathrm{~Hz}, \mathrm{C}_{3}\right)$, $139.0\left(\mathrm{~d},{ }^{3} \mathrm{~J}_{\mathrm{CP}}=4 \mathrm{~Hz}, \mathrm{C}_{2}\right), 135.8\left(\mathrm{C}_{1}\right), 134.3(\mathrm{CH}-\mathrm{Ar}), 132.8\left(\mathrm{~d},{ }^{3} J_{\mathrm{CP}}=\right.$ $\left.7 \mathrm{~Hz}, \mathrm{CH}_{\mathrm{c}}\right), 132.6\left(\mathrm{~d},{ }^{4} J_{\mathrm{CP}}=2 \mathrm{~Hz}, \mathrm{CH}_{\mathrm{d}}\right), 130.4\left(\mathrm{~d},{ }^{1} J_{\mathrm{CP}}=47 \mathrm{~Hz}, \mathrm{C}_{4}\right)$, $129.8\left(\mathrm{CH}_{\mathrm{b}}\right), 128.9\left(\mathrm{CH}_{\mathrm{a}}\right), 125.9(\mathrm{C}-\mathrm{Ar}), 123.8(\mathrm{CH}-\mathrm{Ar}), 123.0(\mathrm{C} \equiv$ $\mathrm{CPh}), \quad 102.4(\mathrm{C} \equiv \mathrm{CPh}), 31.6 \quad\left({ }^{\mathrm{i}} \operatorname{Pr}(\mathrm{CH})\right), 25.7 \quad\left({ }^{\mathrm{i}} \operatorname{Pr}\left(\mathrm{CH}_{3}\right)\right), 23.2$ $\left({ }^{\mathrm{i}} \mathrm{Pr}\left(\mathrm{CH}_{3}\right)\right), 16.9\left(\mathrm{~d},{ }^{1} J_{\mathrm{CP}}=35 \mathrm{~Hz}, \mathrm{PMe}_{2}\right) .{ }^{31} \mathrm{P}\left\{{ }^{1} \mathrm{H}\right\} \mathrm{NMR}(160 \mathrm{MHz}$, $\left.\mathrm{C}_{6} \mathrm{D}_{6}, 25^{\circ} \mathrm{C}\right): \delta$ 9.7. IR (Nujol): $\nu(\mathrm{C} \equiv \mathrm{C}) 2115 \mathrm{~cm}^{-1}$. MS-ESI $(\mathrm{m} / z)$ : calcd for $\mathrm{C}_{40} \mathrm{H}_{48} \mathrm{AuPt}, 756.76$; found, $[\mathrm{M}+\mathrm{H}]$ 757.3, $[\mathrm{M}+\mathrm{Na}]$ 779.3, $[\mathrm{M}+\mathrm{K}]$ 795.3.

Computational Details. Geometry optimization of minima and transition states was carried out with the Gaussian software package. ${ }^{28}$ Optimizations were carried out without symmetry restrictions using the 
$\omega \mathrm{B} 97 \mathrm{xD}$ functional, ${ }^{29}$ which includes empirical dispersion corrections. ${ }^{30}$ The $6-3 \lg (\mathrm{d}, \mathrm{p})$ basis set ${ }^{31}$ was used for nonmetal atoms, and $\mathrm{Au}$ and $\mathrm{Pt}$ atoms were described with the SDD basis and associated electron core potential (ECP). ${ }^{32}$ Bulk solvent effects (dichloromethane) were included during optimization with the SMD continuum model. ${ }^{33}$ Vibrational analysis was carried out on the stationary points to characterize them as minima or transition states as well as to calculate the zero-point corrections, and thermal corrections were made to the enthalpy and free energy. Free energies were corrected $\left(\Delta G_{\mathrm{qh}}\right)$ to account for errors associated with the harmonic oscillator approximation. Thus, according to Truhlar's quasi harmonic approximation, all vibrational frequencies below $100 \mathrm{~cm}^{-1}$ were set to this value so that the entropy contribution was not overestimated. ${ }^{34}$ These anharmonic corrections were calculated with the Goodvibes code. ${ }^{35}$ The CYLview visualization software has been used to create some of the figures. ${ }^{36}$

\section{ASSOCIATED CONTENT}

\section{(s) Supporting Information}

The Supporting Information is available free of charge at https://pubs.acs.org/doi/10.1021/acs.organomet.0c00330.

Additional computational details, X-ray structural data, and NMR spectra of new compounds (PDF)

Cartesian coordinates of the calculated structures (XYZ)

\section{Accession Codes}

CCDC 1965525, 1965526 and 1986501-1986504 contain the supplementary crystallographic data for this paper. These data can be obtained free of charge via www.ccdc.cam.ac.uk/ data_request/cif, or by emailing data_request@ccdc.cam.ac. uk, or by contacting The Cambridge Crystallographic Data Centre, 12 Union Road, Cambridge CB2 1EZ, UK; fax: +44 1223336033.

\section{AUTHOR INFORMATION}

\section{Corresponding Authors}

Joaquín López-Serrano - Instituto de Investigaciones Quimicas (IIQ), Departamento de Quimica Inorgánica and Centro de Innovación en Quimica Avanzada (ORFEO-CINQA), Consejo Superior de Investigaciones Cientificas (CSIC) and University of Sevilla, 41092 Sevilla, Spain; 이이.org/0000-0003-3999-

0155; Email: joaquin.lopez@iiq.csic.es

Jesús Campos - Instituto de Investigaciones Quimicas (IIQ), Departamento de Quimica Inorgánica and Centro de Innovación en Quimica Avanzada (ORFEO-CINQA), Consejo Superior de Investigaciones Cientificas (CSIC) and University of Sevilla, 41092 Sevilla, Spain; 이이. orcid.org/0000-0002-5155-1262; Email: jesus.campos@iiq.csic.es

\section{Authors}

Nereida Hidalgo - Instituto de Investigaciones Quimicas (IIQ), Departamento de Quimica Inorgánica and Centro de Innovación en Quimica Avanzada (ORFEO-CINQA), Consejo Superior de Investigaciones Cientificas (CSIC) and University of Sevilla, 41092 Sevilla, Spain

Juan José Moreno - Instituto de Investigaciones Quimicas (IIQ), Departamento de Quimica Inorgánica and Centro de Innovación en Quimica Avanzada (ORFEO-CINQA), Consejo Superior de Investigaciones Cientificas (CSIC) and University of Sevilla, 41092 Sevilla, Spain; orcid.org/0000-0003-1809-6170

Marina Pérez-Jiménez - Instituto de Investigaciones Quimicas (IIQ), Departamento de Quimica Inorgánica and Centro de Innovación en Quimica Avanzada (ORFEO-CINQA), Consejo Superior de Investigaciones Cientificas (CSIC) and University of Sevilla, 41092 Sevilla, Spain
Celia Maya - Instituto de Investigaciones Químicas (IIQ), Departamento de Quimica Inorgánica and Centro de Innovación en Quimica Avanzada (ORFEO-CINQA), Consejo Superior de Investigaciones Cientificas (CSIC) and University of Sevilla, 41092 Sevilla, Spain

Complete contact information is available at:

https://pubs.acs.org/10.1021/acs.organomet.0c00330

\section{Notes}

The authors declare no competing financial interest.

\section{ACKNOWLEDGMENTS}

This work has been supported by the European Research Council (ERC Starting Grant, CoopCat, Project 756575) and by the Spanish Ministry of Economy and Competitiveness (Project CTQ2016-75193-P [AEI/FEDER, UE]). J.J.M. and M.P.-J. thank the University of Sevilla and the Ministry of Science, Innovation and Universities, respectively, for Ph.D. fellowships. The use of computational facilities at the Supercomputing Centre of Galicia (CESGA) and the Centro de Servicios de Informática y Redes de Comunicaciones (CSIRC), Universidad de Granada, are acknowledged. We gratefully acknowledge Prof. Ernesto Carmona for helpful discussions.

\section{REFERENCES}

(1) (a) Stephan, D. W.; Erker, G. Frustrated Lewis Pair Chemistry: Development and Perspectives. Angew. Chem., Int. Ed. 2015, 54, 64006441. (b) Stephan, D. W.; Erker, G. Frustrated Lewis Pairs II. Top. Curr. Chem. 2013, 334, 1. (c) Stephan, D. W.; Erker, G. Frustrated Lewis Pairs I. Top. Curr. Chem. 2012, 332, 1. (d) Stephan, D. W.; Erker, G. Frustrated Lewis Pairs: Metal-free Hydrogen Activation and More. Angew. Chem., Int. Ed. 2010, 49, 46-76. (e) Stephan, D. W. Frustrated Lewis Pairs. J. Am. Chem. Soc. 2015, 137, 10018-10032. (f) Stephan, D. $\mathrm{W}$. The Broadening Reach of Frustrated Lewis Pair Chemistry. Science 2016, 354, No. aaf7229. (g) Jupp, A. R.; Stephan, D. W. New Directions for Frustrated Lewis Pair Chemistry. Trends in Chemistry 2019, 1, 3548.

(2) Flynn, S. R.; Wass, D. F. Transition Metal Frustrated Lewis Pairs. ACS Catal. 2013, 3, 2574-2581.

(3) For recent examples see: (a) Hamilton, H. B.; King, A. M.; Sparkes, H. A.; Pridmore, N. E.; Wass, D. F. Zirconium-Nitrogen Intermolecular Frustrated Lewis Pairs. Inorg. Chem. 2019, 58, 63996409. (b) Jian, Z.; Daniliuc, C. G.; Kehra, G.; Erker, G. Frustrated Lewis Pair vs Metal-Carbon $\sigma$-Bond Insertion Chemistry at an $o$-PhenyleneBridged $\mathrm{Cp}_{2} \mathrm{Zr}^{+} / \mathrm{PPh}_{2}$ System. Organometallics 2017, 36, 424-434. (c) Jiang, Y.; Blacque, O.; Fox, T.; Berke, H. Catalytic $\mathrm{CO}_{2}$ Activation Assisted by Rhenium Hydride/ $\mathrm{B}\left(\mathrm{C}_{6} \mathrm{~F}_{5}\right)_{3}$ Frustrated Lewis Pairs-Metal Hydrides Functioning as FLP Bases. J. Am. Chem. Soc. 2013, 135, 7751-7760. (d) Simonneau, A.; Turrel, R.; Vendier, L.; Etienne, M. Group 6 Transition-Metal/Boron Frustrated Lewis Pair Templates Activate $\mathrm{N}_{2}$ and Allow its Facile Borylation and Silylation. Angew. Chem., Int. Ed. 2017, 56, 12268-12272. (e) Rahman, M. M.; Smith, M. D.; Amaya, J. A.; Makris, T. M.; Peryshkov, D. V. Activation of C-H Bonds of Alkyl-and Arylnitriles by the $\mathrm{TaCl}_{5}-\mathrm{PPh}_{3}$ Lewis Pair. Inorg. Chem. 2017, 56, 11798-11803. (f) Cui, P.; Comanescu, C. C.; Iluc, V. M. Frustrated Lewis Pair-like Reactions of Nucleophilic Palladium Carbenes with $\mathrm{B}\left(\mathrm{C}_{6} \mathrm{~F}_{5}\right)_{3}$. Chem. Commun. 2015, 51, 6206-6209. (g) Chang, K.; Xu, X. Frustrated Lewis Pair Behavior of a Neutral Scandium Complex. Dalton Trans. 2017, 46, 4514-4517. (h) Wang, Z.; Ying, A.; Fan, Z.; Hervieu, C.; Zhang, L. Tertiary Amino Group in Cationic Gold Catalyst: Tethered Frustrated Lewis Pairs That Enable Ligand-Controlled Regiodivergent and Stereoselective Isomerizations of Propargylic Esters. ACS Catal. 2017, 7, 3676-3680. (i) Barnett, B. R.; Neville, M. L.; Moore, C. E.; Rheingold, A. L.; Figueroa, J. S. Oxidative-Insertion Reactivity Across a Geometrically Constrained Metal $\rightarrow$ Borane Interaction. Angew. Chem., Int. Ed. 2017, 56, 7195- 
7199. (j) Zhang, S.; Appel, A. M.; Bullock, M. Reversible Heterolytic Cleavage of the H-H Bond by Molybdenum Complexes: Controlling the Dynamics of Exchange Between Proton and Hydride. J. Am. Chem. Soc. 2017, 139, 7376-7387. (k) Arndt, S.; Rudolph, M.; Hashmi, A. S. K. Gold-based Frustrated Lewis Acid/Base Pairs (FLPs). Gold Bull. 2017, 50, 267-282. (1) Zwettler, N.; Walg, S. P.; Belaj, F.; MöschZanetti, N. C. Heterolytic Si-H Bond Cleavage at a MolybdenumOxido-Based Lewis Pair. Chem. - Eur. J. 2018, 24, 7149-7160. (m) Chang, K.; Wang, X.; Fan, Z.; Xu, X. Reactions of Neutral Scandium/Phosphorus Lewis Pairs with Small Molecules. Inorg. Chem. 2018, 57, 8568-8580.

(4) Chapman, A. M.; Haddow, M. F.; Wass, D. F. Frustrated Lewis Pairs Beyond the Main Group: Synthesis, Reactivity, and Small Molecule Activation with Cationic Zirconocene-Phosphinoaryloxide Complexes. J. Am. Chem. Soc. 2011, 133, 18463-18478.

(5) Metters, O. J.; Forrest, S. J. K.; SparkesIan, H. A.; Manners, I.; Wass, D. F. Small Molecule Activation by Intermolecular $\mathrm{Zr}(\mathrm{IV})$ Phosphine Frustrated Lewis Pairs. J. Am. Chem. Soc. 2016, 138, 19942003.

(6) (a) Campos, J. Dihydrogen and Acetylene Activation by a Gold(I)/Platinum(0) Transition Metal Only Frustrated Lewis Pair. J. Am. Chem. Soc. 2017, 139, 2944-2947. (b) Hidalgo, N.; Bajo, S.; Moreno, J. J.; Navarro-Gilabert, C.; Mercado, B.; Campos, J. Reactivity of a Gold(I)/Platinum(0) Frustrated Lewis Pair with Germanium and Tin Dihalides. Dalton Trans. 2019, 48, 9127-9138.

(7) Hidalgo, N.; Moreno, J. J.; Pérez-Jiménez, M.; Maya, C.; LópezSerrano, J.; Campos, J. Evidence for Genuine Bimetallic Frustrated Lewis Pair Activation of Dihydrogen with Gold(I)/Platinum(0) Systems. Chem. - Eur. J. 2020, 26, 5982-5993.

(8) (a) Rokob, T. A.; Pápai, I. Hydrogen Activation by Frustrated Lewis Pairs: Insights from Computational Studies. Top. Curr. Chem. 2013, 332, 157-211. (b) Paradies, J. Mechanisms in Frustrated Lewis Pair-Catalyzed Reactions. Eur. J. Org. Chem. 2019, 2019, 283-294. (c) Rocchigiani, L. Experimental Insights into the Structure and Reactivity of Frustrated Lewis Pairs. Isr. J. Chem. 2015, 55, 134-149. (d) Liu, L.; Lukose, B.; Jaque, P.; Ensing, B. Reaction Mechanism of Hydrogen Activation by Frustrated Lewis pairs. Green Energy Environ 2019, 4, 20-28.

(9) Rokob, T. A.; Hamza, A.; Stirling, A.; Pápai, I. On the Mechanism of $\mathrm{B}\left(\mathrm{C}_{6} \mathrm{~F}_{5}\right)_{3}$-Catalyzed Direct Hydrogenation of Imines: Inherent and Thermally Induced Frustration. J. Am. Chem. Soc. 2009, 131, 20292036.

(10) (a) Mahdi, T.; Stephan, D. W. Enabling Catalytic Ketone Hydrogenation by Frustrated Lewis Pairs. J. Am. Chem. Soc. 2014, 136, 15809-15812. (b) Scott, D. J.; Fuchter, M. J.; Ashley, A. E. Nonmetal Catalyzed Hydrogenation of Carbonyl Compounds. J. Am. Chem. Soc. 2014, 136, 15813-15816. (c) Légaré, M. A.; Rochette, E.; Lavergne, J. L.; Bouchard, N.; Fontaine, F. G. Bench-Stable Frustrated Lewis Pair Chemistry: Fluoroborate Salts as Precatalysts for the C-H Borylation of Heteroarenes. Chem. Commun. 2016, 52, 5387-5390.

(11) Legare Lavergne, J.; Jayaraman, A.; Misal Castro, L. C.; Rochette, E.; Fontaine, F.-G. Metal-Free Borylation of Heteroarenes Using Ambiphilic Aminoboranes: On the Importance of Sterics in Frustrated Lewis Pair C-H Bond Activation. J. Am. Chem. Soc. 2017, 139, 1471414723.

(12) (a) Jiang, C.; Blacque, O.; Berke, H. Activation of Terminal Alkynes by Frustrated Lewis Pairs. Organometallics 2010, 29, 125-133. (b) Dureen, M. A.; Brown, C. C.; Stephan, D. W. Deprotonation and Addition Reactions of Frustrated Lewis Pairs with Alkynes. Organometallics 2010, 29, 6594-6607.

(13) Lu, Z.; Ye, H.; Wang, H. New Organoboranes in "Frustrated Lewis Pair" Chemistry. Top. Curr. Chem. 2012, 334, 59-80.

(14) See for example: (a) Dureen, M. A.; Stephan, D. W. Terminal Alkyne Activation by Frustrated and Classical Lewis Acid/Phosphine Pairs. J. Am. Chem. Soc. 2009, 131, 8396-8397. (b) Fukazawa, A.; Yamada, H.; Yamaguchi, S. Phosphonium-and borate-bridged zwitterionic ladder stilbene and its extended analogues. Angew. Chem., Int. Ed. 2008, 47, 5582-5585. (c) Geier, S. J.; Dureen, M. A.; Ouyang, E. Y.;
Stephan, D. W. New Strategies to Phosphino-Phosphonium Cations and Zwitterions. Chem. - Eur. J. 2010, 16, 988-993.

(15) Marín, M.; Moreno, J. J.; Alcaide, M. M.; Álvarez, E.; LópezSerrano, J.; Campos, J.; Nicasio, M. C.; Carmona, E. Evaluating Stereoelectronic Properties of Bulky Dialkylterphenylphosphine Ligands. J. Organomet. Chem. 2019, 896, 120-128.

(16) Goel, R. G.; Srivastava, R. C. Preparation, Characterization, and Some Reactions of Hydridobis(tri-tert-butyl)phosphineplatinum(II) Cation Containing Three-Coordinate Platinum. Can. J. Chem. 1983, 61, 1352-1359.

(17) Ortega-Moreno, L.; Fernández-Espada, M.; Moreno, J. J.; Navarro, C.; Campos, J.; Conejero, S.; López-Serrano, J.; Maya, C.; Peloso, R.; Carmona, E. Synthesis, Properties, and Some Rhodium, Iridium, and Platinum Complexes of a Series of Bulky mTerphenylposphine Ligands. Polyhedron 2016, 116, 170-181.

(18) Espada, M. F.; Campos, J.; López-Serrano, J.; Poveda, M. L.; Carmona, E. Methyl-, Ethenyl-, and Ethynyl-Bridged Cationic Digold Complexes Stabilized by Coordination to a Bulky Terphenylphosphine Ligand. Angew. Chem., Int. Ed. 2015, 54, 15379-15384.

(19) (a) Steinborn, D.; Aisa, A. M. A.; Heinemann, F. W.; Lehmann, S. Synthesis and Structure of a $\mu$-(E)-vinylene-bis[dimethylglyoximato(1)-dimethylglyoximato(2-)-(triphenylphosphine)rhodate] Complex a Vinylene-Bridged Dinuclear Rhodium Complex. J. Organomet. Chem. 1997, 527, 239-245. (b) Wieteck, M.; Vilhelmsen, M. H. L.; Nösel, P.; Schulmeister, J.; Rominger, F.; Rudolph, M.; Pernpointner, M.; Hashmi, A. S. K. Conjugated Vinylgold(I)-Vinylideneruthenium(II) Complexes and Related Organoruthenium Compounds: Stable Analogues of Intermediates Proposed in Dual Gold Catalysis. Adv. Synth. Catal. 2016, 358, 1449-1462.

(20) (a) Arndt, S.; Hansmann, M. M.; Motloch, P.; Rudolph, M.; Rominger, F.; Hashmi, A. S. K. Intramolecular anti-Phosphinoauration of Alkynes: An FLP-Motivated Approach to Stable Aurated Phosphindolium Complexes. Chem. - Eur. J. 2017, 23, 2542-2547. (b) Arndt, S.; Hansmann, M. M.; Rominger, F.; Rudolph, M.; Hashmi, A. S. K. Direct Access to $\pi$-Extended Phosphindolium Salts by Simple Proton-Induced Cyclization of (o-Alkynylphenyl)phosphanes. Chem. Eur. J. 2017, 23, 5429-5433. (c) Arndt, S.; Borstelmann, J.; Saatlo, R. E.; Antoni, P. W.; Rominger, F.; Rudolph, M.; An, Q.; Vaynzof, Y.; Hashmi, A. S. K. The Gold(I)-Mediated Domino Reaction to Fused Diphenyl Phosphoniumfluorenes: Mechanistic Consequences for Gold-Catalyzed Hydroarylations and Application in Solar Cells. Chem. - Eur. J. 2018, 24, 7882-7889.

(21) (a) Brown, T. J.; Widenhoefer, R. A. Cationic Gold(I) $\pi$ Complexes of Terminal Alkynes and Their Conversion to Dinuclear $\sigma, \pi$-Acetylide Complexes. Organometallics 2011, 30, 6003-6009. (b) Hashmi, A. S. K; Lauterbach, T.; Nösel, P.; Vilhelmsen, M. H.; Rudolph, M.; Rominger, F. Dual Gold Catalysis: $\sigma, \pi$-Propyne Acetylide and Hydroxyl-Bridged Digold Complexes as Easy-To-Prepare and Easy-To-Handle Precatalysts. Chem. - Eur. J. 2013, 19, 1058-1065. (c) Zhao, X.; Rudolph, M.; Hashmi, A. S. K. Dual gold catalysis-an update. Chem. Commun. 2019, 55, 12127-12135. (d) Asiri, A. M.; Hashmi, A. S. K. Gold-catalysed reactions of diynes. Chem. Soc. Rev. 2016, 45, 4471-4503.

(22) Guo, Y.; Li, S. A Novel Addition Mechanism for the Reaction of "Frustrated Lewis Pairs" with Olefins. Eur. J. Inorg. Chem. 2008, 2008, 2501-2505.

(23) (a) Debrouwer, W.; Heugebaert, T. S. A.; Roman, B. I.; Stevens, C. V. Homogeneous Gold-Catalyzed Cyclization Reactions of Alkynes with $\mathrm{N}$-and S-Nucleophiles. Adv. Synth. Catal. 2015, 357, 2975-3006. (b) Couce-Rios, A.; Lledós, A.; Fernández, I.; Ujaque, G. Origin of the Anti-Markovnikov Hydroamination of Alkenes Catalyzed by L-Au(I) Complexes: Coordination Mode Determines Regioselectivity. ACS Catal. 2019, 9, 848-858.

(24) See for example: (a) Gimeno, A.; Cuenca, A. B.; Suárez-Pantiga, S.; De Arellano, C. R.; Medio-Simýn, M.; Asensio, G. Competitive Gold-Activation Modes in Terminal Alkynes: An Experimental and Mechanistic Study. Chem. - Eur. J. 2014, 20, 683-688. (b) Hansmann, M. M.; Rominger, F.; Boone, M. P.; Stephan, D. W.; Hashmi, A. S. K. Reactivity of Organogold Compounds with $\mathrm{B}\left(\mathrm{C}_{6} \mathrm{~F}_{5}\right)_{3}$ : Gold-Boron 
Transmetalation via $\sigma$-B/ $\pi$-Au Species. Organometallics 2014, 33, 4461-4470. (c) Grirrane, A.; García, H.; Corma, A.; Álvarez, E. AirStable, Dinuclear and Tetranuclears $\sigma, \pi$-Acetylide Gold(I) Complexes and Their Catalytic Implications. Chem. - Eur. J. 2013, 19, 1223912244. (d) Obradors, C.; Echavarren, A. M. Intermolecular GoldCatalyzed Cycloaddition of Alkynes with Oxoalkenes. Chem. - Eur. J. 2013, 19, 3547-3551. (e) Grirrane, A.; García, H.; Corma, A.; Álvarez, E. Intermolecular [2+2] Cycloaddition of Alkyne-Alkene Catalyzed by $\mathrm{Au}(\mathrm{I})$ Complexes. What Are the Catalytic Sites Involved? ACS Catal. 2011, 1, 1647-1653. (f) Gómez-Suárez, A.; Dupuy, S.; Slawin, A. M. Z.; Nolan, S. P. Straightforward Synthetic Access to gem-Diaurated and Digold $\sigma, \pi$-Acetylide Species. Angew. Chem., Int. Ed. 2013, 52, 938942.

(25) Uson, R.; Laguna, A.; Laguna, M.; Briggs, D. A.; Murray, H. H.; Fackler, J. P. (Tetrahydrothiophene)gold(I) or gold(III) Complexes. Inorg. Synth. 2007, 26, 85-91.

(26) Jaw, H. R. C.; Mason, W. R. Electronic Absorption and MCD Spectra for Isoelectronic Linear Two-Coordinate Bis(tri-tert-butylphosphine)metal Complexes of Platinum(0) and Gold(I). Inorg. Chem. 1989, 28, 4370-4373.

(27) Wan, X.-K.; Cheng, X.-L.; Tang, Q.; Han, Y.-Z.; Hu, G.; Jiang, D.; Wang, Q.-M. Atomically Precise Bimetallic $\mathrm{Au}_{19} \mathrm{Cu}_{30}$ Nanocluster with an Icosidodecahedral $\mathrm{Cu}_{30}$ Shell and an Alkynyl-Cu Interface. J. Am. Chem. Soc. 2017, 139, 9451-9554.

(28) Frisch, M. J.; Trucks, G. W.; Schlegel, H. B.; Scuseria, G. E.; Robb, M. A.; Cheeseman, J. R.; Scalmani, G.; Barone, V.; Mennucci, B.; Petersson, G. A.; Nakatsuji, H.; Caricato, M.; Li, X.; Hratchian, H. P.; Izmaylov, A. F.; Bloino, J.; Zheng, G.; Sonnenberg, J. L.; Hada, M.; Ehara, M.; Toyota, K.; Fukuda, R.; Hasegawa, J.; Ishida, M.; Nakajima, T.; Honda, Y.; Kitao, O.; Nakai, H.; Vreven, T.; Montgomery, J. A., Jr.; Peralta, J. E.; Ogliaro, F.; Bearpark, M.; Heyd, J. J.; Brothers, E.; Kudin, K. N.; Staroverov, V. N.; Keith, T.; Kobayashi, R.; Normand, J.; Raghavachari, K.; Rendell, A.; Burant, J. C.; Iyengar, S. S.; Tomasi, J.; Cossi, M.; Rega, N.; Millam, J. M.; Klene, M.; Knox, J. E.; Cross, J. B.; Bakken, V.; Adamo, C.; Jaramillo, J.; Gomperts, R.; Stratmann, R. E.; Yazyev, O.; Austin, A. J.; Cammi, R.; Pomelli, C.; Ochterski, J. W.; Martin, R. L.; Morokuma, K.; Zakrzewski, V. G.; Voth, G. A.; Salvador, P.; Dannenberg, J. J.; Dapprich, S.; Daniels, A. D.; Farkas, O.; Foresman, J. B.; Ortiz, J. V.; Cioslowski, J.; Fox, D. J. Gaussian 09, Rev. B.01; Gaussian, Inc.: Wallingford CT, 2010.

(29) Chai, J.-D.; Head-Gordon, M. Long-range corrected hybrid density functionals with damped atom-atom dispersion corrections. Phys. Chem. Chem. Phys. 2008, 10, 6615-6620.

(30) Grimme, S. Semiempirical GGA-type density functional constructed with a long-range dispersion correction. J. Comput. Chem. 2006, 27, 1787-1799.

(31) (a) Ditchfield, R.; Hehre, W. J.; Pople, J. A. Self-Consistent Molecular-Orbital Methods. IX. An Extended Gaussian-Type Basis for Molecular-Orbital Studies of Organic Molecules. J. Chem. Phys. 1971, 54, 724-728. (b) Hehre, W. J.; Ditchfield, R.; Pople, J. A. SelfConsistent Molecular Orbital Methods. XII. Further Extensions of Gaussian-Type Basis Sets for Use in Molecular Orbital Studies of Organic Molecules. J. Chem. Phys. 1972, 56, 2257-2261. (c) Hariharan, P. C.; Pople, J. A. The Influence of Polarization Functions on Molecular Orbital Hydrogenation Energies. Theor. Chim. Acta 1973, 28, 213-222. (d) Francl, M. M.; Pietro, W. J.; Hehre, W. J.; Binkley, J. S.; Gordon, M. S.; DeFrees, D. J.; Pople, J. A. Self-Consistent Molecular Orbital Methods. XXIII. A Polarization-Type Basis Set for Second-Row Elements. J. Chem. Phys. 1982, 77, 3654-3665.

(32) Andrae, D.; Haeussermann, U.; Dolg, M.; Stoll, H.; Preuss, H. Energy-Adjusted Ab Initio Pseudopotentials for the Second and Third Row Transition Elements. Theor. Chim. Acta 1990, 77, 123-141.

(33) Marenich, A. V.; Cramer, C. J.; Truhlar, D. G. Universal Solvation Model Based on Solute Electron Density and on a Continuum Model of the Solvent Defined by the Bulk Dielectric Constant and Atomic Surface Tensions. J. Phys. Chem. B 2009, 113, 6378-6396.

(34) Ribeiro, R. F.; Marenich, A. V.; Cramer, C. J.; Truhlar, D. G. Use of Solution-Phase Vibrational Frequencies in Continuum Models for the Free Energy of Solvation. J. Phys. Chem. B 2011, 115, 14556-14562.
(35) Funes-Ardoiz, I.; Paton, R. S. Goodvibes 2.0.2, 2016; DOI: $10.5281 /$ zenodo.595246.

(36) Legault, C. Y. CYLview, 1.0b; Université de Sherbrooke: 2009; http://www.cylview.org. 